\title{
Distribution and chronological framework for Iberian variscite mining and consumption at Pico Centeno, Encinasola, Spain
}

\author{
Carlos P. Odriozola ${ }^{\text {a,* }}$, Rodrigo Villalobos García ${ }^{\text {b }}$, Christopher I. Burbidge c, Rui Boaventura ${ }^{\text {d }}$, Ana C. Sousa ${ }^{\text {, }}$ \\ Oliva Rodríguez-Ariza ${ }^{\mathrm{e}}$, Rubén Parrilla-Giraldez ${ }^{\mathrm{a}}$, M. Isabel Prudênçio ${ }^{\mathrm{c}}$, María Isabel Dias ${ }^{\mathrm{c}}$ \\ a Department of Prehistory and Archaeology, University of Seville, María de Padilla S/N, 41004 Sevilla, Spain \\ b Department of Prehistory, Archaeology, Social Anthropology and Historiographic Sciences and techniques, University of Valladolid, Pz/ del Campus S/N, 47011 Valladolid, Spain \\ c Centre for Nuclear Science and Technology, IST, University of Lisbon, E.N. 10 ao km 139,7, 2695-066 Bobadela LRS, Portugal \\ d Centre for Archaeology, University of Lisbon, Alameda da Universidade 1600-214 Lisboa, Portugal \\ e Andalusian Centre for Ibearian Archaeology, University of Jaén, Paraje Las Lagunillas s/n, Jaén, Spain
}

\section{A R T I C L E I N F O}

Article history:

Received 8 May 2015

Available online 8 January 2016

\section{Keywords:}

Variscite

Mining

OSL

14C-AMS

Iberia

Pico Centeno

\begin{abstract}
A B S T R A C T
AMS radiocarbon and OSL dating, and profiling were used to directly delimit periods of variscite production at Pico Centeno Mine 2. These results were integrated with analysis of other well-dated periods of variscite production to establish an Iberian-wide chronological framework. Variscite production at Pico Centeno Mine 2 began at $\sim 5200$ BC, coincident with alpine jade production or Casa Montero Iberian flint production. Variscite was only used occasionally, together with other greenstones, during the 5th and 6th millennia BC. During the 4th millennium BC, variscite use began to increase to its apogee in the first half of 3rd millennium BC when it appeared in nearly every Iberian burial site. This increase in variscite production and use coincided with decline in the popularity of alpine jade. By the end of the 3rd millennium BC, new resources began to be valued such as Asian and African Ivory, Baltic and Sicilian amber, and copper-based metal products. The variscite cycle thus started with the decline of jade in the 5th-4th millennium BC, and ended with the appearance of copper, ivory and extra-peninsular amber by the end of the 3rd millennium BC.
\end{abstract}

(C) 2015 University of Washington. Published by Elsevier Inc. All rights reserved.

\section{Introduction}

Archaeological literature devoted to green body ornaments in Prehistoric Europe has thematically focused, almost exclusively, on the quest for the origin of these artefacts. Since the early 20th century, interpretations of the geographical origin of these 'perles du calais' traversed continents, from Middle East turquoise mines to European variscite mines, initially pointing to a French origin at Montebras (Balagny, 1939), then later to the Pannacé aluminophosphate mines (Massé, 1971; Forestier et al., 1973a,1973b; Lheur, 1993), and finally to a Spanish origin at the Palazuelo de las Cuevas (Arribas et al., 1970, 1971) and Can Tintorer (Alonso et al., 1978; Bosch and Estrada, 1995; Villalba, 2002) variscite mines.

Since the 1970s, research devoted to 'calaite' beads has focussed on locating and characterising further new variscite sources. Source areas have been discovered at Bragança in Northeast Portugal (Meireles et al., 1987), at the Sarrabus deposit in Sardinia (Marini et al., 1989), at the variscite and turquoise outcrops of Punta Corveiro in Spain (Moro et al., 1995), and at the Pico Centeno variscite mines in Spain (Nocete and Linares, 1999; Fig. 1). This focus on identifying geological mineral

\footnotetext{
* Corresponding author. Fax: + 34954559920.

E-mail address: codriozola@us.es (C.P. Odriozola).
}

sources has been driven by the view that their relationships to archaeological bead assemblages can be established by the intercomparison of their chemical compositions (Edo i Benaiges et al., 1995a; Dominguez Bella, 2004; Odriozola, 2014; Odriozola et al., 2010; Querré et al., 2014, 2008).

To date, most papers devoted to beads continue to use calaite and variscite as synonyms. However, the increase in geochemical analyses of green mineral sources was paralleled by an increase in the numbers of analyses of 'calaite' beads, and thus in the knowledge of the minerals used in beadmaking. Beads were found to include green mica, steatite, turquoise, talc and chlorite (Dominguez Bella, 2012). Therefore, calaite and variscite should not be considered synonyms, and the validity of the traditional analysis of variscite flows and consumption patterns (e.g., Dominguez Bella, 2012) is called into question. As the number of analysed beads increases, it becomes more apparent that Neolithic, Copper Age, and Bronze Age communities used nearly any available green mineral for beadmaking.

The current consensus on the geographic focus of European variscite body ornament production points to Palazuelo de las Cuevas (Aliste, Zamora), Can Tintorer (Gavá, Barcelona) and Pico Centeno (Encinasola, Huelva; Dominguez Bella, 2004; Herbaut and Querré, 2004; Querré et al., 2008, 2014; Odriozola et al., 2010; Odriozola, 2014). The chronological span of variscite production is less clear, however. Arribas et al. 


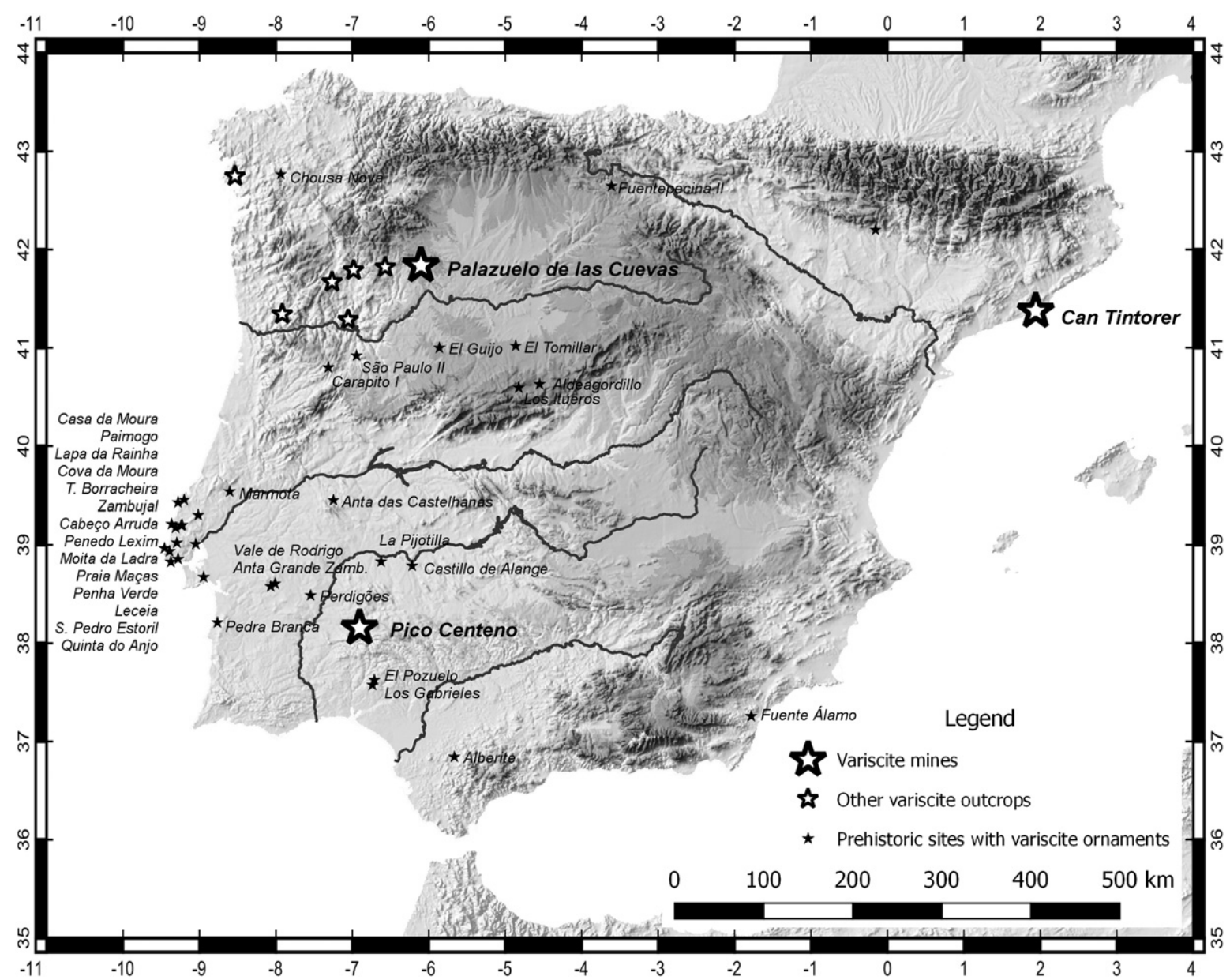

Figure 1. Location of known Iberian variscite sources.

(1970, 1971) proposed that variscite production occurred during the Arabic period at Palazuelo de las Cuevas, based on the assumption that the city of Zamora was named after the Arabic word for emerald (zamarrad). Virgilio Sevillano (1978) and Campano Lorenzo et al. (1985) instead found that Roman pottery and prismatic blanks were associated with bead production at Las Cercas, and Copper Age variscite mining has been proposed at La Mazada (Sanz Mínguez, et al., 1990; Esparza Arroyo and Larrazabal Galarza, 2000). Both Las Cercas and La Mazada form part of the Palazuelo de las Cuevas complex. Meanwhile, Can Tintorer has been extensively dated to the Late Neolithic, between $\sim 4500$ and $3500 \mathrm{BC}$, based on burials, charcoals and seeds found in direct association with the mine galleries (Table 1).

Jiménez Gómez (1995) attempted to chronologically order variscite production patterns at the Zambujal site (Torres Vedras, Central Portugal), based on radiocarbon ages and on mineralogical analysis. They concluded that production was mainly prehistoric; initially a mixture of greenstones was used, then variscite use dominated the second half of the 3rd millennium BC. Villalobos García (2012) has shown that this preference for variscite over other greenstones during the second half of the 3rd millennium BC also occurred in the northern Spanish Meseta.

Analyses of variscite exchange patterns have concentrated nearly exclusively on source and/or bead geochemistry (Alonso et al., 1978; Blasco et al., 1990; Dominguez Bella, 2004, 1996; Edo i Benaiges and Fernández Turiel, 1997; Edo i Benaiges et al., 1995a, 1995b; Edo i Benaiges et al., 1990; Fernández Turiel et al., 1996; Querré et al., 2008). Provenance analysis and consumption patterns often pinpoint a geological source that lacks not only evidence of production but also of any local human activity during periods relevant to the beads in question. No evaluation has been undertaken of the beads' archaeological relevance to the socioeconomic likelihood for exploitation of a source in a given locale during a given period.

In contrast to settlements, mines usually do not constitute wellstratified sites; instead, they constitute a complex system of use, reuse and re-location of products (Frumkin et al., 2014). Little, if any, datable material survives in direct stratigraphic association with the mined surface. In addition, mines usually experience several periods of production. Therefore, dating mining sites is challenging and is usually based on: 1) time period-specific mine typology and/or mining technology (tool marks and debris); 2) artefacts typology; and 3) delimitation of production by dating materials found in spoil and/ or immediately pre-production contexts. Dating prehistoric mines based on typology and technology is therefore difficult. In Iberia, dating has resulted in chronological frameworks that span Late Prehistory without a clear delineation into different late prehistoric periods (Domergue, 1990; Hunt, 2003).

The production chronology at Pico Centeno is controversial. Nocete and Linares (1999) identified three trench mines and Pérez Macías (2011, 2008) considered them to represent the Bronze Age and Roman copper exploitation. However, Pérez Macías (2008) argues that marks left on the extraction face by metal tools at Pico Centeno may represent soundings made in 1883 by the Mina de Cobre Santo Tomás (Jubes and Carbonell, 1920). Also, a Neolithic-Chalcolithic variscite production period has been proposed recently based on the Pico Centeno Mine 2 (PCM2) typology, the typo-technological marks on the surface of the mine, the typology of the mining tools, and indirectly by dating of contexts in which worked variscite beads, thought to originate from Pico Centeno, were found (Odriozola et al., 2010; Odriozola, 2014). 
Table 1

Available radiocarbon ages for European mining resources. Calibrated ages with $2 \sigma$ uncertainty.

\begin{tabular}{|c|c|c|c|c|c|c|c|}
\hline \multirow[t]{2}{*}{ Lab. code } & \multirow[t]{2}{*}{ Site } & \multirow{2}{*}{$\frac{14 \text { age }}{\text { yr BP }}$} & \multirow{2}{*}{$\frac{\text { Uncertainty }}{+/-\mathrm{yr}}$} & \multirow{2}{*}{$\frac{\delta^{13} \mathrm{C}}{\text { per mil }}$} & \multirow{2}{*}{$\frac{\text { Calibrated age }}{\mathrm{yr} B C}$} & \multirow[t]{2}{*}{ Mineral } & \multirow[t]{2}{*}{ Reference } \\
\hline & & & & & & & \\
\hline Can Tintorer & I-12730 & 4310 & 150 & 0 & $3365-2497$ & variscite & Villalba et al. (1986) \\
\hline Can Tintorer & I-12731 & 5350 & 190 & 0 & 4594-3713 & variscite & Villalba et al. (1986) \\
\hline Can Tintorer & I-11786 & 5070 & 100 & 0 & $4142-3645$ & variscite & Villalba et al. (1986) \\
\hline Can Tintorer & UBAR-41 & 4970 & 100 & 0 & $3973-3534$ & variscite & Villalba et al. (1986) \\
\hline Can Tintorer & CSIC-488 & 4710 & 50 & 0 & $3634-3371$ & variscite & Villalba et al. (1986) \\
\hline Can Tintorer & CSIC-489 & 4940 & 50 & 0 & $3912-3639$ & variscite & Villalba et al. (1986) \\
\hline Can Tintorer & I-12158 & 4880 & 100 & 0 & 3943-3379 & variscite & Villalba et al. (1986) \\
\hline Can Tintorer & UBAR-42 & 4820 & 100 & 0 & $3891-3366$ & variscite & Villalba et al. (1986) \\
\hline Can Tintorer & I-13099 & 4820 & 100 & 0 & $3701-3350$ & variscite & Villalba et al. (1986) \\
\hline Can Tintorer & UBAR-49 & 4740 & 90 & 0 & $3766-3091$ & variscite & Villalba et al. (1986) \\
\hline Can Tintorer & UBAR-30 & 4710 & 130 & 0 & $3658-3105$ & variscite & Villalba et al. (1986) \\
\hline Can Tintorer & UBAR-48 & 4690 & 100 & 0 & $3633-3036$ & variscite & Villalba et al. (1986) \\
\hline Can Tintorer & UBAR-47 & 4610 & 90 & 0 & $3365-2497$ & variscite & Villalba et al. (1986) \\
\hline Can Tintorer & $\mathrm{I}-12730$ & 4310 & 150 & 0 & 3654-3039 & variscite & Villalba et al. (1986) \\
\hline Can Tintorer & Beta-61491 & 4660 & 110 & 0 & $3943-3538$ & variscite & Bosch and Estrada (1994) \\
\hline Can Tintorer & Beta-72551 & 4930 & 70 & 0 & $3946-3662$ & variscite & Bosch and Estrada (1994) \\
\hline Can Tintorer & Beta-72552 & 5000 & 60 & 0 & $4038-3715$ & variscite & Bosch and Estrada (1994) \\
\hline Can Tintorer & Beta-72553 & 5100 & 60 & 0 & $4325-3791$ & variscite & Bosch and Estrada (1994) \\
\hline S. Ferreres & Beta-155686 & 5220 & 110 & 0 & $3943-3674$ & variscite & Borrell et al. (2009) \\
\hline S. Ferreres & Beta-250402 & 5000 & 40 & 0 & $3935-3657$ & variscite & Borrell et al. (2009) \\
\hline S. Ferreres & Beta-250403 & 4980 & 40 & 0 & $3935-3657$ & variscite & Borrell et al. (2009) \\
\hline S. Ferreres & Beta-250405 & 4980 & 40 & 0 & $3943-3704$ & variscite & Borrell et al. (2009) \\
\hline S. Ferreres & Beta-250406 & 5010 & 40 & 0 & $3943-3704$ & variscite & Borrell et al. (2009) \\
\hline S. Ferreres & Beta-250404 & 5010 & 40 & 0 & $5471-5322$ & variscite & Borrell et al. (2009) \\
\hline Casa Montero & Beta-206512 & 6410 & 40 & -24.2 & 5324-5077 & silex & Díaz del Rio and Consuegra Rodríguez (2011) \\
\hline Casa Montero & Beta-206513 & 6270 & 40 & -26.2 & $5468-5229$ & silex & Díaz del Rio and Consuegra Rodríguez (2011) \\
\hline Casa Montero & Beta-232884 & 6360 & 40 & -25.4 & $5358-5080$ & silex & Díaz del Rio and Consuegra Rodríguez (2011) \\
\hline Casa Montero & Beta-232885 & 6280 & 40 & -24.9 & $5466-5225$ & silex & Díaz del Rio and Consuegra Rodríguez (2011) \\
\hline Casa Montero & Beta-232886 & 6350 & 40 & -25.6 & $5367-5208$ & silex & Díaz del Rio and Consuegra Rodríguez (2011) \\
\hline Casa Montero & Beta-232887 & 6290 & 40 & -22.2 & $5310-5066$ & silex & Díaz del Rio and Consuegra Rodríguez (2011) \\
\hline Casa Montero & Beta-232888 & 6240 & 40 & 0 & $5367-5208$ & silex & Díaz del Rio and Consuegra Rodríguez (2011) \\
\hline Casa Montero & Beta-232889 & 6290 & 40 & -22.3 & $5533-5371$ & silex & Díaz del Rio and Consuegra Rodríguez (2011) \\
\hline Casa Montero & Beta-232890 & 6500 & 40 & -25.6 & $5458-5215$ & silex & Díaz del Rio and Consuegra Rodrígue (2011) \\
\hline Casa Montero & Beta-232891 & 6320 & 40 & -26.2 & 5324-5077 & silex & Díaz del Rio and Consuegra Rodríguez (2011) \\
\hline Casa Montero & Beta-232892 & 6270 & 40 & -26.2 & $5463-5217$ & silex & Díaz del Rio and Consuegra Rodríguez (2011) \\
\hline Casa Montero & Beta-232893 & 6330 & 40 & -25.6 & $6009-5727$ & silex & Díaz del Rio and Consuegra Rodríguez (2011) \\
\hline Defensola & UTC-1342 & 6990 & 80 & 0 & $5887-5568$ & flint & Díaz del Rio et al. (2008) \\
\hline Defensola & Beta-71143 & 6820 & 80 & 0 & $4683-4362$ & flint & Díaz del Rio et al. (2008) \\
\hline Defensola & Beta-71144 & 5670 & 70 & 0 & $5666-5475$ & flint & Díaz del Rio et al. (2008) \\
\hline Defensola & Beta-80604 & 6630 & 70 & 0 & $5616-5376$ & flint & Díaz del Rio et al. (2008) \\
\hline Defensola & Beta-80603 & 6540 & 60 & 0 & $5626-5492$ & flint & Díaz del Rio et al. (2008) \\
\hline Defensola & UTC-1411 & 6630 & 40 & 0 & $5295-4860$ & flint & Díaz del Rio et al. (2008) \\
\hline Tomaszów & GrN-7594 & 6145 & 70 & 0 & $5300-4746$ & flint & Díaz del Rio et al. (2008) \\
\hline Krzemionki & Gd-1425 & 6090 & 110 & 0 & $4612-4367$ & flint & Díaz del Rio et al. (2008) \\
\hline Porco & AA-62119 & 5665 & 47 & 0 & 4829-4559 & jadeite & Petrequin et al. (2006) \\
\hline Porco & AA-62120 & 5847 & 47 & 0 & $5212-4910$ & jadeite & Petrequin et al. (2006) \\
\hline Porco & AA-62121 & 6110 & 48 & 0 & $4960-4721$ & jadeite & Petrequin et al. (2006) \\
\hline Porco & AA-62123 & 5959 & 49 & 0 & $5218-4953$ & jadeite & Petrequin et al. (2006) \\
\hline Porco & AA-62122 & 6146 & 49 & 0 & 4934-4712 & jadeite & Petrequin et al. (2006) \\
\hline Porco & AA-62125 & 5931 & 48 & 0 & 5309-5056 & jadeite & Petrequin et al. (2006) \\
\hline Porco & AA-62124 & 6231 & 48 & 0 & 265-535 AD & jadeite & Petrequin et al. (2006) \\
\hline Bule & AA-66511 & 1644 & 36 & 0 & $4340-4068$ & jadeite & Petrequin et al. (2006) \\
\hline Bule & AA-66512 & 5393 & 42 & 0 & $4517-4353$ & jadeite & Petrequin et al. (2006) \\
\hline Bule & AA-66513 & 5605 & 42 & 0 & $4517-4353$ & jadeite & Petrequin et al. (2006) \\
\hline Bule & AA-66514 & 5662 & 71 & 0 & $4682-4357$ & jadeite & Petrequin et al. (2006) \\
\hline Bule & AA-66515 & 6222 & 44 & 0 & $5303-5056$ & jadeite & Petrequin et al. (2006) \\
\hline Bule & AA-66516 & 5963 & 61 & 0 & $4996-4716$ & jadeite & Petrequin et al. (2006) \\
\hline Bule & AA-66517 & 6212 & 71 & 0 & $5323-4986$ & jadeite & Petrequin et al. (2006) \\
\hline Cabrieres & Beta-156929 & 3830 & 40 & 0 & $2458-2148$ & copper & Ambert (2002) \\
\hline Cabrieres & Beta-156928 & 3900 & 40 & 0 & $2480-2212$ & copper & Ambert (2002) \\
\hline Araico & Beta-312351 & 5640 & 40 & 0 & $4545-4367$ & Silex & Tarriño et al. (2011) \\
\hline Araico & Beta-312352 & 6050 & 40 & 0 & $5054-4838$ & Silex & Tarriño et al. (2011) \\
\hline Tomaszów & & 6220 & 120 & 0 & $5467-4852$ & Silex & Tarriño et al. (2011) \\
\hline Tomaszów & & 6145 & 70 & 0 & $5295-4860$ & Silex & Tarriño et al. (2011) \\
\hline Tomaszów & & 5700 & 70 & 0 & $4707-4371$ & Silex & Tarriño et al. (2011) \\
\hline Blackpatch & BM-290 & 5090 & 130 & 0 & $4230-3643$ & silex & Tarriño et al. (2011) \\
\hline Church Hill & BM-181 & 5340 & 150 & 0 & $4460-3800$ & silex & Whittle et al. (2011) \\
\hline Cissbury & BM-183 & 4720 & 150 & 0 & $3892-3023$ & silex & Whittle et al. (2011) \\
\hline Cissbury & BM-184 & 4650 & 150 & 0 & $3700-2932$ & silex & Whittle et al. (2011) \\
\hline Cissbury & BM-185 & 4730 & 150 & 0 & 3907-3026 & silex & Whittle et al. (2011) \\
\hline Cissbury & BM-3082 & 5100 & 60 & -19.2 & $4038-3715$ & silex & Whittle et al. (2011) \\
\hline Cissbury & BM-3086 & 4710 & 60 & -22.1 & $3634-3370$ & silex & Whittle et al. (2011) \\
\hline Harrow Hill & BM-182 & 4930 & 150 & 0 & $4040-3370$ & silex & Whittle et al. (2011) \\
\hline
\end{tabular}


Table 1 (continued)

\begin{tabular}{|c|c|c|c|c|c|c|c|}
\hline \multirow[t]{2}{*}{ Lab. code } & \multirow[t]{2}{*}{ Site } & \multirow{2}{*}{$\frac{14 \text { age }}{\text { yr BP }}$} & \multirow{2}{*}{$\frac{\text { Uncertainty }}{+/-\mathrm{yr}}$} & \multirow{2}{*}{$\frac{\delta^{13} \mathrm{C}}{\text { per mil }}$} & \multirow{2}{*}{$\frac{\text { Calibrated age }}{\mathrm{yr} B C}$} & \multirow[t]{2}{*}{ Mineral } & \multirow[t]{2}{*}{ Reference } \\
\hline & & & & & & & \\
\hline Harrow Hill & BM-2099R & 5040 & 120 & -23.1 & $4225-3536$ & silex & Whittle et al. (2011) \\
\hline Harrow Hill & BM-2097R & 5140 & 150 & -25.2 & 4319-3651 & silex & Whittle et al. (2011) \\
\hline Harrow Hill & BM-2071R & 4900 & 120 & -26.7 & $3960-3377$ & silex & Whittle et al. (2011) \\
\hline Harrow Hill & BM-2075R & 5020 & 110 & -26.4 & 4044-3539 & silex & Whittle et al. (2011) \\
\hline Harrow Hill & BM-2124R & 5060 & 90 & -24.9 & $4037-3657$ & silex & Whittle et al. (2011) \\
\hline Harrow Hill & BM-2098R & 5350 & 150 & -25.7 & $4486-3802$ & silex & Whittle et al. (2011) \\
\hline Harrow Hill & BM-3084 & 4880 & 30 & -21.9 & $3706-3638$ & silex & Whittle et al. (2011) \\
\hline Harrow Hill & BM-3085 & 5070 & 50 & -23.4 & $3970-3715$ & silex & Whittle et al. (2011) \\
\hline Long Down & OxA-1152 & 5050 & 100 & 0 & $4041-3647$ & silex & Whittle et al. (2011) \\
\hline Spiennes & Lv-1566 & 5510 & 55 & 0 & $4458-4259$ & silex & Collet (2004), Collet et al. (2008) \\
\hline Spiennes & GrN-4674 & 5420 & 75 & 0 & $4444-4046$ & silex & Collet (2004), Collet et al. (2008) \\
\hline Spiennes & Lv-1598 & 5100 & 65 & 0 & 4039-3713 & silex & Collet (2004), Collet et al. (2008) \\
\hline Spiennes & KN-I.16 & 5110 & 40 & 0 & $3980-3797$ & silex & Collet (2004), Collet et al. (2008) \\
\hline Spiennes & OxA-3196 & 4830 & 80 & 0 & $3778-3376$ & silex & Collet (2004), Collet et al. (2008) \\
\hline Spiennes & Beta-194770 & 4580 & 40 & 0 & 3499-3105 & silex & Collet (2004), Collet et al. (2008) \\
\hline Spiennes & Beta-194771 & 4550 & 40 & 0 & $3484-3100$ & silex & Collet (2004), Collet et al. (2008) \\
\hline Spiennes & Beta-110683 & 4500 & 50 & 0 & $3361-3027$ & silex & Collet (2004), Collet et al. (2008) \\
\hline El Milagro (Asturias) & OxA-3005 & 3990 & 90 & 0 & $2865-2210$ & copper & Collet (2004), Collet et al. (2008) \\
\hline El Milagro (Asturias) & OxA-3006 & 3850 & 90 & 0 & 2567-2036 & copper & de Blas Cortina (2011) \\
\hline El Milagro (Asturias) & Ua-33207 & 3785 & 35 & 0 & $2338-2051$ & copper & de Blas Cortina (2011) \\
\hline El Milagro (Asturias) & Ua-33209 & 3775 & 35 & 0 & $2331-2043$ & copper & de Blas Cortina (2011) \\
\hline El Milagro (Asturias) & Ua-24538 & 3630 & 40 & 0 & 2133-1892 & copper & de Blas Cortina (2011) \\
\hline El Milagro (Asturias) & Ua-24537 & 3520 & 40 & 0 & 1950-1704 & copper & de Blas Cortina (2011) \\
\hline El Milagro (Asturias) & Ua-24550 & 3355 & 45 & 0 & $1747-1527$ & copper & de Blas Cortina (2011) \\
\hline El Milagro (Asturias) & Ua-33206 & 3285 & 35 & 0 & $1643-1460$ & copper & de Blas Cortina (2011) \\
\hline La Profunda (León) & Ua-35778 & 3865 & 35 & 0 & 2464-2209 & copper & de Blas Cortina (2011) \\
\hline La Profunda (León) & Ua-35779 & 3950 & 35 & 0 & $2570-2310$ & copper & de Blas Cortina (2011) \\
\hline La Profunda (León) & Ua-35780 & 4075 & 35 & 0 & $2858-2490$ & copper & de Blas Cortina (2011) \\
\hline El Aramo (Asturias) & OxA-1833 & 4090 & 70 & 0 & $2872-2488$ & copper & de Blas Cortina (2011) \\
\hline El Aramo (Asturias) & OxA-1926 & 3810 & 70 & 0 & $2466-2040$ & copper & de Blas Cortina (2011) \\
\hline El Aramo (Asturias) & OxA-3007 & 3900 & 90 & 0 & $2623-2057$ & copper & de Blas Cortina (2011) \\
\hline El Aramo (Asturias) & OxA-6789 & 3995 & 50 & 0 & $2833-2345$ & copper & de Blas Cortina (2011) \\
\hline El Aramo (Asturias) & Ua-18629 & 3775 & 65 & -21.4 & $2456-2028$ & copper & de Blas Cortina (2011) \\
\hline El Aramo (Asturias) & Ua-18630 & 3365 & 60 & -20.1 & $1872-1504$ & copper & de Blas Cortina (2011) \\
\hline El Aramo (Asturias) & Ua-18631 & 3310 & 65 & -20.4 & $1743-1446$ & copper & de Blas Cortina (2011) \\
\hline El Aramo (Asturias) & Ua-18632 & 3825 & 60 & -20.5 & 2467-2062 & copper & de Blas Cortina (2011) \\
\hline El Aramo (Asturias) & Ua-18633 & 3940 & 60 & -20.1 & $2580-2210$ & copper & de Blas Cortina (2011) \\
\hline El Aramo (Asturias) & Ua-18634 & 3215 & 55 & -22 & $1623-1327$ & copper & de Blas Cortina (2011) \\
\hline Chiflón & BM-1600 & 4840 & 50 & 0 & $3756-3389$ & copper & Acosta (1995) \\
\hline Chiflón & BM-1599 & 4780 & 50 & 0 & $3654-3378$ & copper & Acosta (1995), Castro Martínez et al. (1996) \\
\hline Chiflón & OxTL-200e3(II) & 4000 & 300 & 0 & $3353-1744$ & copper & Acosta (1995) \\
\hline Rio Tinto & BM-2337R & 2650 & 140 & 0 & $1121-406$ & copper & Castro Martínez et al. (1996) \\
\hline Chiflón & BM-1529 & 3320 & 130 & 0 & 1939-1297 & copper & Burleigh et al. (1982), Rothenberg and Frejeiro (1980) \\
\hline Chiflón & BM-1528 & 2650 & 60 & 0 & $972-590$ & copper & Burleigh et al. (1982), Rothenberg and Frejeiro (1980) \\
\hline Chiflón & BM-1601 & 2520 & 210 & & $1190-108$ & copper & Burleigh et al. (1982), Rothenberg and Frejeiro (1980) \\
\hline
\end{tabular}

The dating of variscite mines is a crucial step to evaluate variscite production, consumption, and its socio-cultural significance. As such, our paper focuses on directly dating the exploitation of PCM2 by means of the combined luminescence and radiocarbon dating of three features. One of the features is an extraction face in which we found charcoal in the base level. This may relate to the setting of fire against a rock face to weaken it and so facilitate mining. The second feature is a pit that we suggest corresponds to a later phase of mining activity, and the third consists of tailings located adjacent to the face and pit. We also use indirect dating of PCM2 through the analysis of well-dated contexts containing variscite artefacts. Both the direct and indirect chronological datasets will be at the centre of a debate focussed on the production of a tentative model for Iberian variscite production and consumption.

\section{PCM2 direct dating}

The outcrop of the Pico Centeno aluminophosphate deposit includes three opencast trench mines. The typology of the mines resembles those of prehistoric mining activity (Shepherd, 1980; Domergue, 1990; Craddock, 1995; Hunt, 1996, 2003).

We performed an excavation in PCM2, where we conducted 5 test cuts (A-to-D) in 2011 (Fig. 2). In addition to early extraction activity, indicated by small cavities following variscite veins, and tool-marking scars created by mallets and hammerstones, we also detected an excavation made by metallic picks that could date from Roman times to the 20th century 'copper fever' (Pérez Macías, 2008, after Jubes and Carbonell, 1920).

In summary, prehistoric features at PCM2 include an access ramp cut into the rock, a central transit area, and an extraction face with small cavities. These are characterised by concave marks left by the impact of rounded-edged tools (Odriozola and Villalobos García, 2015; and see Craddock, 1995, for a detailed summary of the mining technology). A 2 m deep pit near the access area suggests additional non-prehistoric production, which cut the prehistoric facies, and has marks left on the extraction face by metal tools.

In addition to the possibility that PCM2 was mined in recent times, the mining tools found during excavations, including quartzite cobbles, chisels and picks, point to prehistoric use. This most likely relates to an early stage of variscite exploitation during Late Prehistory.

\section{Stratigraphy}

Pico Centeno, similar to many other mines in Iberia, exhibits a long history of use, re-use, and re-location of products and debris, which results in a complex stratigraphy (Fig. 3). 


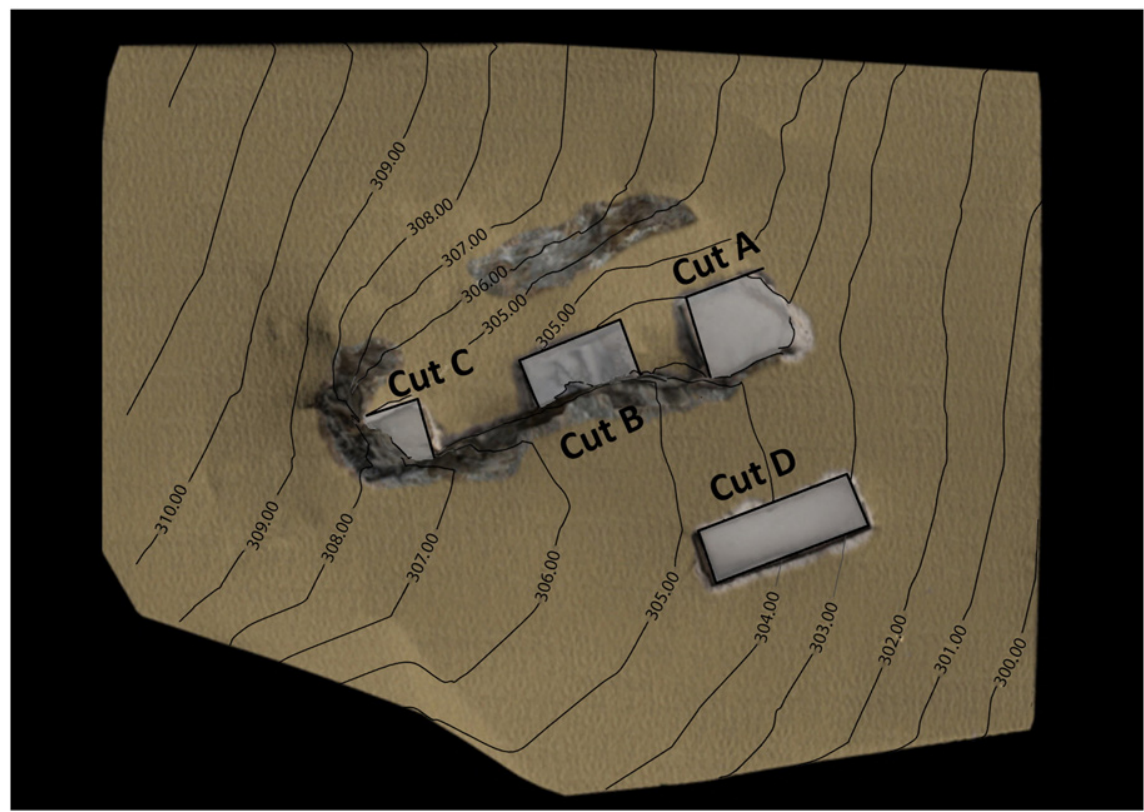

Figure 2. Test cut position and 3D model. Pico Centeno's PCM2 extraction face location is $38.161534738^{\circ} \mathrm{N} / 6.949741517^{\circ} \mathrm{W}$ (WGS84, EPSG: 4326 ).

In cut B at PCM2 (Fig. 3), horizontal sedimentary units were identified through the stratigraphy. These are interpreted as floor units that are associated with the mining activities and movement of materials to the exterior of the mine. A deep excavated pit was recorded to cut these floor units (cut B, Fig. 3).
The last floor unit (test cut A SU 9, test cut B SU 11 and test cut C SU 12/13) used before the abandonment of the mine contained numerous stone tools such as picks and wedges that show strong use wear, small production debris with concave marks, and charcoal remains that adhere to both the extraction faces and the floor. We argue that the

\section{A}
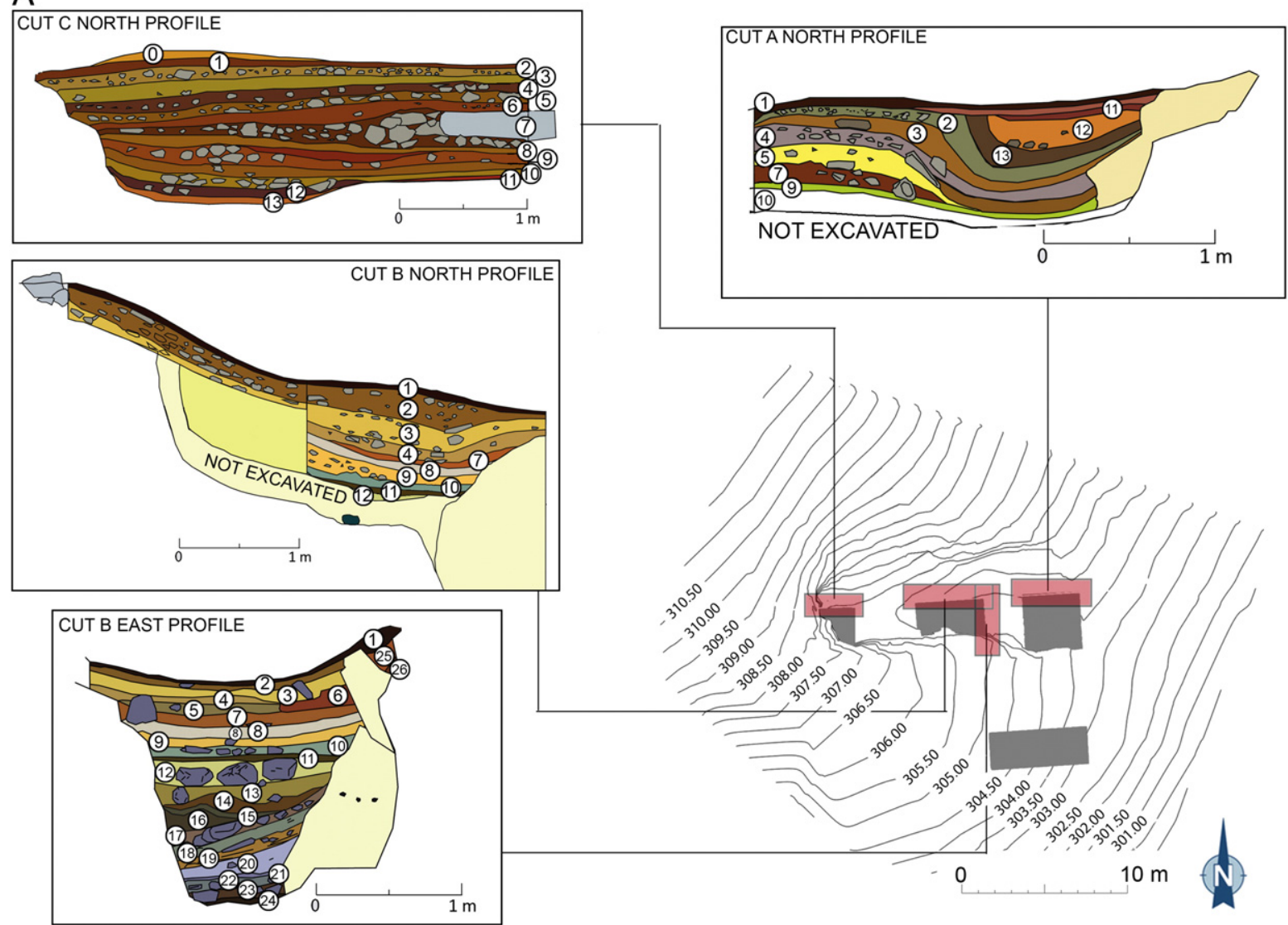

Figure 3. A) PCM2 planimetry and cuts A, B and C North profiles and cut B East profile stratigraphies; B) Harris matrix of cut B (software matrix Harris composer). 
B

Natural deposion [
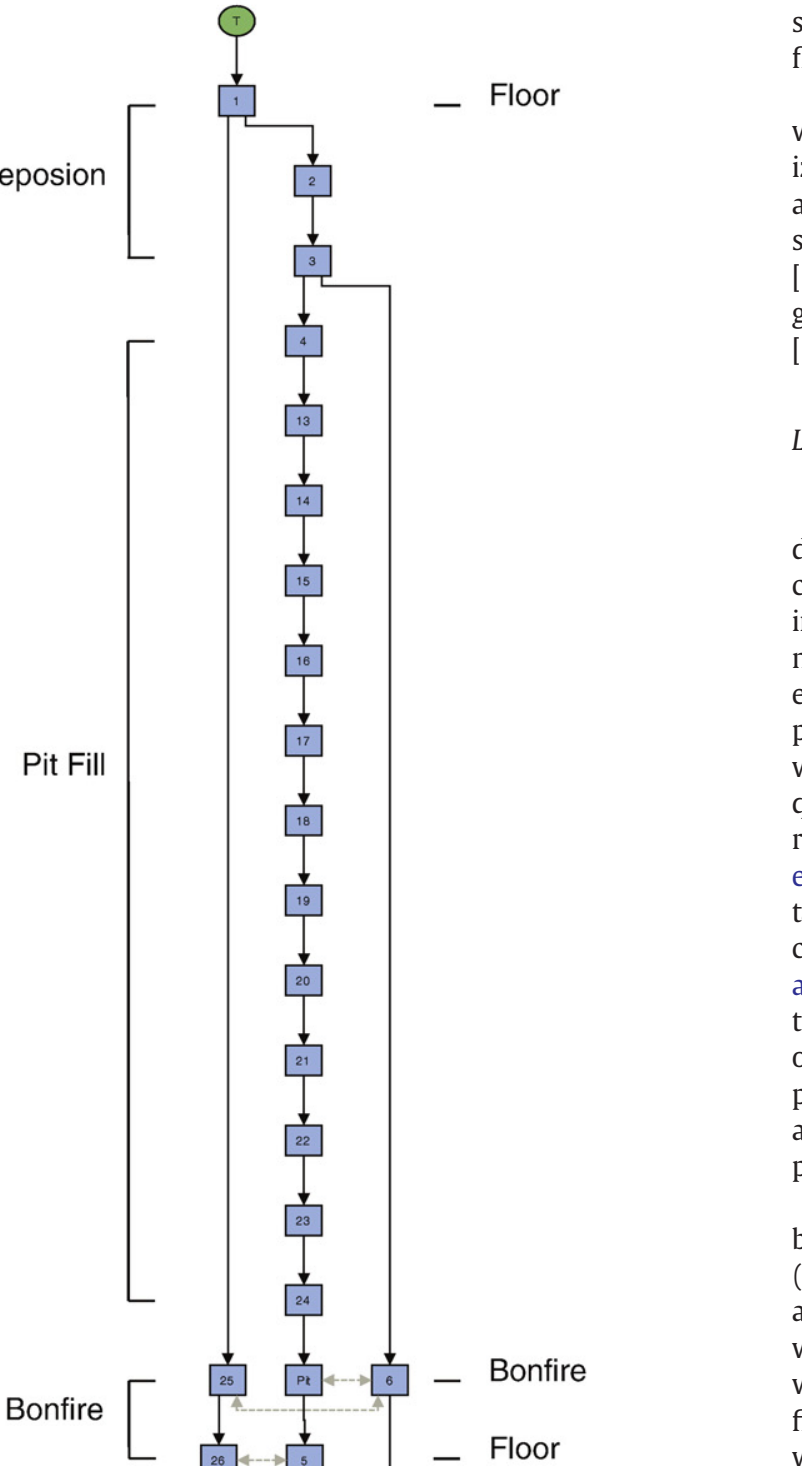

after abandonment. The mid sequence contained a series of oblique stony units that may indicate an episode of intentional human infill [SU 16-20], and this infill were capped by several relatively finegrained sub-horizontal units indicative of gradual (natural) deposition [SU 13-15] (Figs. 3 and 4).

\section{Luminescence dating}

In this study, two complementary approaches to luminescence dating analysis were used. Semi-quantitative luminescence profiling combines simple sample preparation with multi-signal measurement: infrared- (IRSL), optically- (OSL) and thermally- (TSL) stimulated luminescence, of numerous small samples from around a site. This enables evaluation of dominant luminescence signals to guide subsequent sample preparation and fully quantitative analysis; it provides indications of whether material has been heated or not, and efficiently produces semiquantitative estimates of absorbed dose with elevated stratigraphic resolution (Sanderson et al., 2001; Burbidge et al., 2007; Rodrigues et al., 2013; Odriozola et al., 2014). Thirteen profiling samples were taken using stainless steel tubes $2 \mathrm{~cm}$ diameter and $5 \mathrm{~cm}$ long from the cut B section (Figs. 2 and 4), plus two from the base of cut C (Figs. 2 and 3 ). The unexcavated volume of material remaining in cut $C$ was too small for a quantitative dating tube: quantitative dating analyses of a lesser number of larger samples were made using OSL. These comprised three tubes, $3.8 \mathrm{~cm}$ in diameter and $15 \mathrm{~cm}$ long, of sediment and a piece of rock from cut B (units 6, 11, 13 \& 18 in Fig. 4; Table 2), plus a tube of sediment from cut D (ITNLUM 701).

The east section of test cut B was chosen for OSL dating and profiling because it was the deepest available stratigraphic section at the site (Fig. 4) and was initially expected to include both prehistoric facies and the more modern pit fills. Samples for quantitative OSL dating were taken from the least stony layers (Table 2). In addition, one rock was collected to test whether the tailings included material to which fire had been set to facilitate mining. The remaining stratigraphic units were sampled for semi-quantitative luminescence profiling to test the severity of the residual signals in the stonier layers and/or to help delimit the phases of accumulation. The two additional profiling tubes were extracted from the remaining regolith at the base of cut C, close to the ${ }^{14} \mathrm{C}$ sample locations, to test the chronological relations between the cuts and between the OSL and ${ }^{14} \mathrm{C}$ dating results. The sample taken for quantitative analysis from the south section of cut D (ITNLUM 701) was designed to help evaluate the chronological relation between the fills in cut B and the layers of tailings spread around the mine site.

\section{Luminescence and dosimetric measurements}

In luminescence dating, the dose of ionising radiation absorbed by a crystal (absorbed dose, measured in Gy) since a heating or light exposure event of sufficient severity, is evaluated by comparing TSL or OSL signal from the as-prepared sample with those from laboratory irradiations (Burbidge, 2012, 2015). Comparison of doses from TSL and OSL can thus indicate whether a sample was heated or exposed to light. Assuming that the absorbed dose resulted from long-lived radionuclides in a fixed geometry, the dose rate (measured in $\mathrm{Gy} / \mathrm{ka}$ ) may be calculated from parent radionuclide concentrations of the sample or in situ dose rate measurements. Luminescence measurements were made on 3 Risø DA-15 and DA-20 readers using integrated ${ }^{90} \mathrm{Sr} /{ }^{90} \mathrm{Y}$ irradiators calibrated relative to the primary ${ }^{60} \mathrm{Co}$ standard of LPSR and CTN metrology laboratory (Reader 1, $75 \pm 4 \mathrm{mGy} / \mathrm{s} \beta$; Reader 2, $95 \pm 3 \mathrm{mGy} / \mathrm{s} \beta$; Reader 3, $111 \pm 3 \mathrm{mGy} / \mathrm{s}(3)$. abundance of charcoal in the base level and on the surface indicates the use of fire-setting technology (Willies, 1994; Craddock, 1995; Weisgerber and Willies, 2000). The floor units were sealed by apparently rapid accumulations of large and medium size rock blocks, which indicates human infilling with debris. The rubble was sealed by several apparently slower, natural, accumulation units, which were in turn sealed by a recent compact ground surface layer that is similar to the

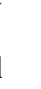



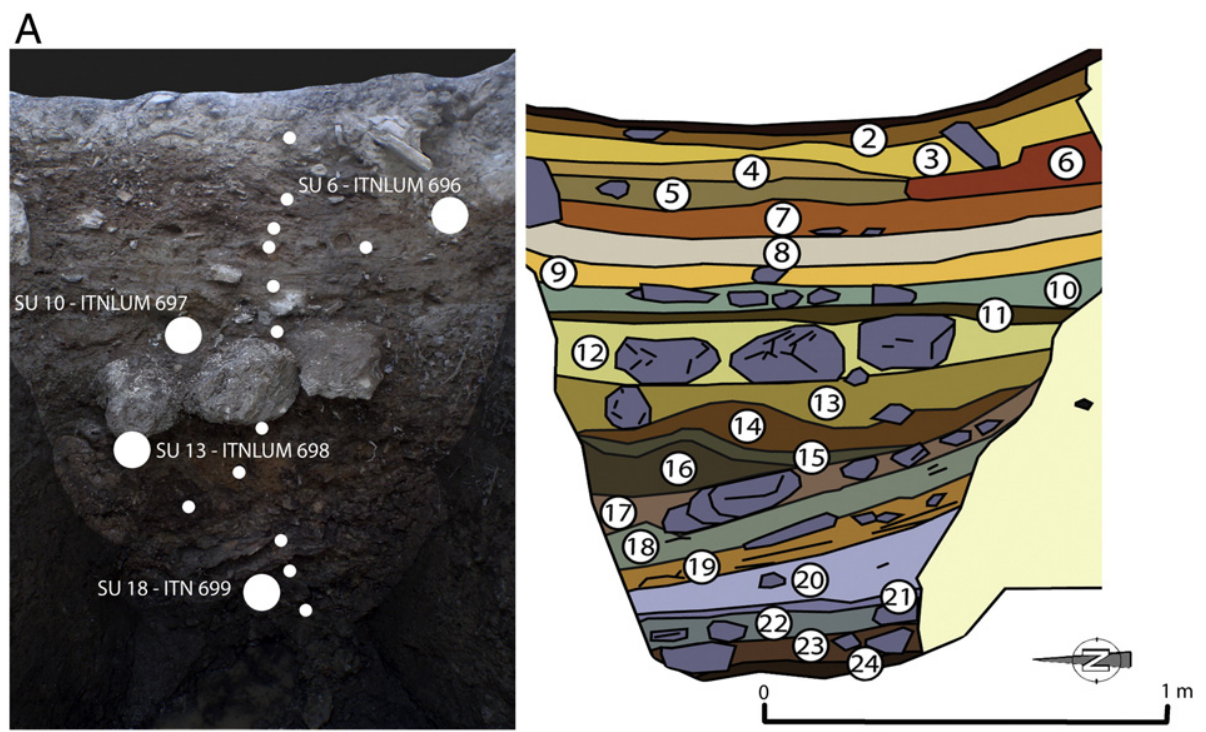

B CUTD
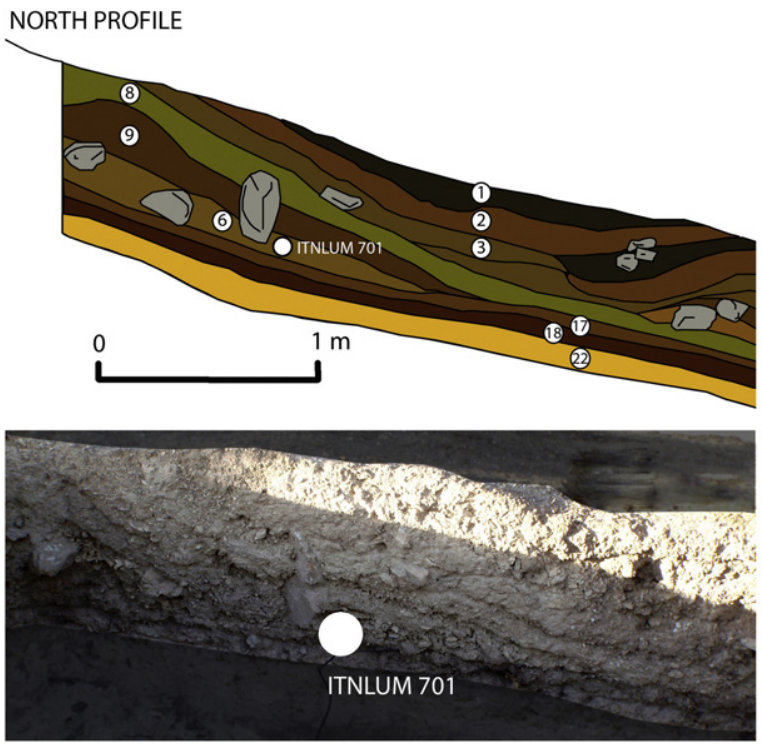

Figure 4. A) Cut B East profile stratigraphy and B) cut D North profile stratigraphy, with the detailed quantitative OSL sample position (big dots) and semi-quantitative OSL profiling (small dots).

For semi-quantitative luminescence profiling (Sanderson et al., 2001), a basic series of preparatory treatments was used to separate coarse (90-250 $\mu \mathrm{m}$ ) $40 \% \mathrm{HF}$ etched fractions enriched in quartz; they were measured using a simple multi-stimulation protocol (Rodrigues et al., 2013; Odriozola et al., 2014). The profiling approaches referred

Table 2

Brief description of the units sampled for OSL dating.

\begin{tabular}{|c|c|c|c|}
\hline Sample \# & Cut & Unit & Description \\
\hline ITNLUM 696 & B & 6 & A bonfire nearby the extraction surface \\
\hline ITNLUM 697 & B & 10 & $\begin{array}{l}\text { Rock sample. This unit seems to be directly related } \\
\text { with the last episode of prehistoric exploitation. } \\
\text { This unit accounts for the } 15 \% \text { of the stone tools } \\
\text { recovered. Units are cut by the pit. }\end{array}$ \\
\hline ITNLUM 698 & B & 13 & $\begin{array}{l}\text { It is interpreted as a modern depositional unit } \\
\text { filling the pit. }\end{array}$ \\
\hline ITNLUM 699 & B & 18 & $\begin{array}{l}\text { Take part of the oblique depositional units that fills } \\
\text { the pit with big rock blocks. }\end{array}$ \\
\hline ITNLUM 701 & $\mathrm{D}$ & 6 & $\begin{array}{l}\text { Depositional unit, believed to be part of production } \\
\text { debris accumulation. }\end{array}$ \\
\hline
\end{tabular}

to above have calibrated signals from the as-prepared material on an aliquot-to-aliquot basis, using signals that resulted from a single regenerative dose in the quasi-linear region of the sample's dose response. In the present case, the as-prepared signals from the profiling samples varied strongly and were often much greater than those produced by the calibration dose (e.g. Burbidge et al., 2007). The extrapolation of the quasi-linear calibration dose response would tend to overestimate the signal that resulted from doses in the range of 10-200 Gy, in which the effects of saturation in the dose response, particularly from quartz, would be expected to be evident. To help explain the signal saturation and to permit comparison between all results, the absorbed doses of the profiling samples were estimated by using a common saturating exponential dose response characteristic (DRC). This was obtained directly from the profiling measurements. It was defined by using the average of the standardised (Roberts and Duller, 2004) postIR OSL responses to $50 \mathrm{~s} \beta$, with test dose of $10 \mathrm{~s} \beta$ used in all analyses (Burbidge et al., 2006), all measured on Reader 3. The DRC is described by a single saturating exponential function, $I=I_{\infty}(1-\exp (-D / \bar{D})$ using a signal at saturation $\left(I_{\infty}\right)$ equal to the average dose of signal saturation $(\bar{D})$ (Burbidge, 2015), which was found to be $40 \mathrm{~Gy}$. Semi- 
quantitative age values were estimated by interpolating the total dose rates calculated for the quantitative dating samples.

In this study, sampling and analysis for quantitative luminescence dating were undertaken using the methods of Burbidge et al. (2014), which are based on a combination of instrumental neutron activation analysis (INAA, Dias et al., 2013; Dias and Prudêncio, 2007; Gouveia and Prudêncio, 2000; Prudêncio et al., 2006), high resolution gamma spectrometry (HRGS, Trindade et al., 2013), field gamma spectrometry (FGS; Trindade et al., 2014), water absorption and retention under free drainage, and OSL measurements. In the present case FGS was conducted using both Target Nanospec and HPI Rainbow Multi Channel Analysers, each with $2^{\prime \prime} \times 2^{\prime \prime}$ NaI probes.

Water content was measured as a fraction of dry sample mass $\left(50^{\circ} \mathrm{C}\right)$ with the sample in its as-received or 'field' state, once saturated, and following free drainage for $1 \mathrm{~h}$, and 1, 2, 4 and 8 days $\left(\mathrm{W}_{\mathrm{f}}, \mathrm{W}_{\mathrm{s}}, \mathrm{W}_{\mathrm{D} 0-8}\right.$; Burbidge et al., 2014). One end of each sediment sample tube was sealed with tape and the other end was closed with nylon mesh; the rock was brushed clean of loose material and weighted $\left(\mathrm{W}_{\mathrm{f}}\right)$. Inverted tubes and the rock were soaked overnight in deionised water and weighed after removal of standing water (Ws). Tubes were then unsealed and set to drain on an inclined board; the rock was drained on an inclined sieve $\left(\mathrm{W}_{\mathrm{DO}-8}\right)$. Fills that were rich in weathered pelitic host rock were highly water retentive; the clast-rich mine-waste and the sample of rock drained more completely. Differences between $\mathrm{K}$ and Th concentrations estimated by FGS, HRGS and INAA (Tables 3a and 3b) were explainable using attenuation by $\mathrm{W}_{\mathrm{f}}$ for the more deeply buried samples. Representative drained values were used for samples from superficial, i.e., drier layers (ITNLUM 696,701 ). Sampling was conducted in late autumn, in days following rain: well-drained ground had not been subject to prolonged wetting and was expected to retain a slightly greater than minimum water content, whereas samples from the poorly drained pit had been subject to prolonged wetting and were expected to retain greater than average water contents. On this basis the time averaged burial values for the fill and rock samples (ITNLUM 696-9) were estimated as the average of $\mathrm{W}_{\mathrm{f}}$ for each sample and that of the driest sample (ITNLUM 701); the upper value in the average calculation for ITNLUM 701 was chosen as $W_{D 8}$.

The mineralisation associated with the precipitation of aluminophosphates to produce variscite at PCM2 apparently also resulted in the presence of moderately elevated levels of $U$ (Tables 3a and $3 \mathrm{~b}$ ). Therefore, to test for disequilibrium in the upper U-series, HRGS was performed for each quantitative dating analysis. 23-31 g of milled material was sealed and equilibrated in polystyrene Petri dishes. Twenty five emission lines from ${ }^{40} \mathrm{~K}$ and the ${ }^{235} \mathrm{U},{ }^{238} \mathrm{U}$ and ${ }^{232} \mathrm{Th}$ decay series were mass-normalised and compared with the reference samples GSS1, GSS5, GSR6 used for INAA. Significant disequilibrium in the upper series was not apparent, and the weighted mean results over all emissions yielded similar results to the INAA (Tables $3 a$ and $3 b$ ). However, after accounting for in situ water content, $\mathrm{U}$ dose rates obtained from (unsealed) FGS measurements were $10 \%-30 \%$ lower than INAA (parent ${ }^{238} \mathrm{U}$ ) or the weighted mean HRGS (sealed). Given the relatively wet conditions in the pit at the time of sampling, the low FGS results are considered to indicate minimum ${ }^{222} \mathrm{Rn}$ loss in the field. Since this appeared to better approximate burial conditions in the fills and mine wastes, the FGS $U$ values were chosen for age calculations for samples ITNLUM 696, 697, 699 and 701.

The cosmic dose rate was estimated by averaging values calculated based on as-sampled burial depth and the height of the adjacent rock. Calculations were based on Prescott and Stephan (1982) and a fit to the data of Prescott and Hutton (1988).

With respect to the OSL analyses per se, the pelitic host rock produced abundant fine silica, the agglomerates of which exhibited slow OSL signal decay, poor recycling and strong recuperation in the single aliquot regenerative (SAR) OSL protocol (Murray and Wintle, 2000). Relatively small quantities of $90-160 \mu \mathrm{m}$ size quartz were obtained for quantitative OSL analyses: this required repeated disaggregation, sieving, cleaning with $\mathrm{HCl}$, density separation, $\mathrm{HF}$ dissolution $(40 \%$, $40 \mathrm{~min}$ ), and re-sieving. In the analyses ITNLUM 696, 697, 699, 701, the calibration curve used the following radiation exposures: 0 (As-prepared), 20, 0, 5, 10, 40, 80, 0, 20, 20 (IR) $s \beta$; test dose $D_{T}=10 \mathrm{~s} \beta$ (the reader used to measure each sample is listed in Tables $3 \mathrm{a}$ and $3 \mathrm{~b}$ ), and the results were fitted with a single saturating exponential. Initial tests indicated that the quartz grains from sample PCM3 yielded relatively low OSL signals but high absorbed dose values. Thus, in the analysis ITNLUM 698 the calibration curve used exposures of: 0 (As-prepared), $200,0,800,1600,3200,6400,0,200,200$ (IR) $s \beta ; D_{T}=50 \mathrm{~s} \beta$, and the results were fitted with a saturating exponential plus linear function. In all cases, preheats were made at $180,200,220,240,260$ and $280^{\circ} \mathrm{C}$ / $30 \mathrm{~s}$ to test for differences in the absorbed dose estimates as a function of the relative filling of, and/or transfer of the charges between, electron and hole traps during calibration and test irradiations and OSL measurements. All measurements that used the 180 and $280^{\circ} \mathrm{C} / 30$ s preheats were rejected in the analyses of ITNLUM 696, 697, 699 and 701, since systematic deviations or increased scatter in absorbed dose values were commonly observed. For ITNLUM 698, scatter in the absorbed dose estimates was great for all preheats, and the test-normalised OSL signal from the as-prepared material did not intercept the calibration curve in two cases (Tables 3a and 3b). For the accepted measurements in each analysis, the average recycling ratios ranged from 0.93 to 1.01 , and from 0.96 to 1.00 (0.81, ITNLUM 698) after exposure to infrared light. The average zero dose responses were $<6 \%$ of the average absorbed doses. The OSL signal per unit dose was relatively low for samples from the pit (Tables 3a and 3b), and for ITNLUM 698 it declined by $50 \%$ during the measurement sequence. Signal integrals that used the majority of the initial OSL decay as signal, with 'late' background subtraction, were therefore applied for dating calculations in all cases. Use of the initial signal gradient, i.e., counts in the third and fourth channels subtracted from those in the first two channels measured during OSL, resulted in highly dispersed datasets.

The weighted mean (1/variance) appeared consistent with the main grouping of accepted absorbed dose measurements in the analyses of ITNLUM 696, 697, 699, and 701, and was used to calculate central absorbed dose estimates for use in age calculation. However, individual

Table 3a

Luminescence dating measurements: radionuclide concentrations and estimates of water content.

\begin{tabular}{|c|c|c|c|c|c|c|c|c|c|c|c|c|c|c|c|}
\hline \multirow[t]{3}{*}{ PCMII } & \multirow[t]{3}{*}{ ITNLUM } & \multirow[t]{3}{*}{ Sample type ${ }^{a}$} & \multirow{3}{*}{$\begin{array}{l}\text { Depth }^{\text {b }} \\
(\mathrm{cm})\end{array}$} & \multicolumn{3}{|c|}{ FGS in situ ${ }^{c}$} & \multirow{3}{*}{$\begin{array}{l}\mathrm{H}_{2} \mathrm{O} \text { in situ } \\
(\mathrm{g} / \mathrm{g})\end{array}$} & \multicolumn{3}{|c|}{ HRGS lab, dry } & \multirow{3}{*}{$\mathrm{U}$} & \multicolumn{3}{|c|}{ INAA lab, dry } & \multirow{3}{*}{$\begin{array}{l}\frac{\mathrm{H}_{2} \mathrm{O}}{\text { Time averaged }} \\
(\mathrm{g} / \mathrm{g})\end{array}$} \\
\hline & & & & \multirow{2}{*}{$\frac{\mathrm{K}}{(\%)}$} & Th & $\mathrm{U}$ & & \multirow{2}{*}{$\frac{\text { Ref. }}{\mathrm{A} 10 /}$} & \multirow{2}{*}{$\frac{\mathrm{K}}{(\%)}$} & Th & & \multirow{2}{*}{$\frac{\mathrm{K}}{(\%)}$} & Th & $\mathrm{U}$ & \\
\hline & & & & & (pp & & & & & (ppm) & & & \multicolumn{2}{|l|}{$\overline{(\mathrm{ppm})}$} & \\
\hline 1 & 696 & $\mathrm{~T}$ & 30 & 1.5 & 9.1 & 7.6 & 0.37 & 256 & 2.4 & 13 & 16 & 2.2 & 12 & 14 & 0.10 \\
\hline 2 & 697 & $\mathrm{~T}$ & 53 & 1.7 & 9.6 & 7.9 & 0.36 & 257 & 2.3 & 14 & 15 & 2.3 & 12 & 14 & 0.19 \\
\hline 3 & 698 & $\mathrm{R}$ & 86 & 1.5 & 8.7 & 7.6 & 0.37 & 258 & 1.8 & 11 & 13 & 1.9 & 11 & 11 & 0.19 \\
\hline 4 & 699 & $\mathrm{~T}$ & 132 & 1.8 & 7.3 & 14 & 0.38 & 259 & 2.6 & 14 & 23 & 2.6 & 12 & 23 & 0.20 \\
\hline 5 & 701 & $\mathrm{~T}$ & 47 & 1.7 & 11 & 8.1 & 0.08 & 260 & 1.8 & 12 & 14 & 1.7 & 12 & 13 & 0.09 \\
\hline \multicolumn{4}{|c|}{ Average uncertainty } & 0.1 & 1.2 & 1.1 & 0.02 & & 0.1 & 1.8 & 0.6 & 0.2 & 0.7 & 0.4 & 0.15 \\
\hline
\end{tabular}

a Tube; rock.

b Below pre-excavation ground level.

c As measured, i.e. not corrected for in situ water content. 
Table 3b

Luminescence dating measurements: summary dose rate, absorbed dose, and calendar date estimates.

\begin{tabular}{|c|c|c|c|c|c|c|c|c|c|c|c|c|c|c|c|c|c|}
\hline \multirow[t]{3}{*}{ PCMII } & \multirow[t]{3}{*}{ ITNLUM } & \multirow[t]{3}{*}{ Sample Type ${ }^{a}$} & \multirow{3}{*}{$\begin{array}{l}\text { Depth }^{\mathrm{b}} \\
\overline{(\mathrm{cm})}\end{array}$} & \multicolumn{5}{|c|}{ Dose rate } & \multicolumn{3}{|l|}{ OSL } & \multicolumn{3}{|c|}{ Absorbed dose } & \multicolumn{3}{|c|}{ Calendar age } \\
\hline & & & & $\dot{D}_{\text {Cosmic }}$ & $\sigma_{\dot{D}}$ & $\dot{D}_{\text {total }}$ & $\sigma_{\dot{D}}$ & & Reader & Aliquots & $\overline{\bar{I}_{T 1}{ }^{\mathrm{d}}}$ & $\bar{D}$ & $\sigma_{D}$ & & \multirow[b]{2}{*}{ Date } & & \\
\hline & & & & \multicolumn{2}{|c|}{$\left(\mathrm{mGy} \mathrm{a}^{-1}\right)$} & \multicolumn{2}{|c|}{$\left(\mathrm{mGy} \mathrm{a}^{-1}\right)$} & \multicolumn{2}{|l|}{$=|<|>/ ?^{c}$} & $\overline{/ 24}$ & $\overline{(\mathrm{cts})}$ & \multicolumn{2}{|c|}{$\left(\mathrm{Gy}{ }^{60} \mathrm{Co}\right)$} & $=|<|>/ ?^{c}$ & & \multicolumn{2}{|l|}{$\sigma_{\text {age }}$} \\
\hline 1 & 696 & $\mathrm{~T}$ & 30 & 0.14 & 0.04 & 5.60 & 0.29 & $=$ & 2 & 16 & 420 & 0.63 & 0.09 & $=$ & 1900 & 20 & $\mathrm{AD}$ \\
\hline 2 & 697 & $\mathrm{~T}$ & 53 & 0.13 & 0.04 & 5.25 & 0.38 & $=$ & 2 & 16 & 215 & 0.73 & 0.09 & $=$ & 1870 & 20 & $\mathrm{AD}$ \\
\hline 3 & 698 & $\mathrm{R}$ & 86 & 0.12 & 0.03 & 4.79 & 0.31 & $=$ & 1 & 22 & 186 & 55 & 11 & $?$ & 9000 & 2000 & $\mathrm{BC}$ \\
\hline 4 & 699 & $\mathrm{~T}$ & 132 & 0.12 & 0.03 & 6.97 & 0.59 & $=$ & 3 & 16 & 362 & 1.34 & 0.19 & $>$ & 1820 & 30 & $\mathrm{AD}$ \\
\hline 5 & 701 & $\mathrm{~T}$ & 47 & 0.22 & 0.01 & 4.79 & 0.27 & $=$ & 3 & 16 & 2380 & 1.08 & 0.12 & $>$ & 1790 & 30 & $\mathrm{AD}$ \\
\hline
\end{tabular}

absorbed doses measured by OSL from the rock (ITNLUM 698) exhibited scatter to very high values, so that the weighted mean for this sample is considered merely to indicate a minimum estimate. These OSL results, and comparison of OSL and TSL in test measurements indicate that the rock was not heated: finite OSL measurements are thought to have been due to the aforementioned poor behaviour within the SAR protocol.

For age estimation, the different measurements were combined in accordance with the approach outlined in Burbidge et al. (2014). Alpha, beta and gamma dose rates from the environment that surrounded the sample location were estimated from FGS measurements, after correcting for measurement geometry and the difference between the in situ and the time averaged water contents. The attenuated environmental dose rates were combined with the self-dose rate of a volume of representative size and density for the adjunct samples taken from the holes excavated for FGS measurement. This was based on the dimensions of the holes, radionuclide concentrations from INAA and HRGS (U from FGS) on material from the adjunct sample, and the time-averaged water contents estimated from measurements on the tube samples. The attenuated dose rates from the environment and the adjunct were then combined with similarly estimated values for the samples themselves; for the tube samples the water content and radionuclide concentrations were assumed equal to the adjunct. The dose rates to the etched cores of the quartz grains measured by OSL were calculated from these values, and all were combined with calculated cosmic dose rates to estimate the total dose rates for the grains measured by luminescence. For each sample, the weighted mean OSL absorbed dose estimate from the grains was divided by the dose rate to estimate the age, which was converted an estimate the calendar age.

\section{AMS-radiocarbon dating}

Radiocarbon measurements were performed using a 1 MV accelerator mass spectrometer (AMS) at the facilities of the University of Sevilla (Centro Nacional de Aceleradores) on 5 charcoal samples recovered at the base level of test cut C (unit 12/13).

The chemical preparation of the samples followed standard procedures (Santos Arevalo et al., 2009). A Soxhlet extraction was applied using hexane, acetone and ethanol before treating the samples with the Acid-Alkali-Acid cleaning procedure (AAA). For the AAA procedure, $0.5 \mathrm{M} \mathrm{HCl}$ and $0.1 \mathrm{M} \mathrm{NaOH}$ were used, and time was carefully controlled to avoid severe losses by dissolution.

Between 7-10 mg of clean and dry charcoal was combusted at $950^{\circ} \mathrm{C}$ for $3 \mathrm{~h}$ in a vacuum-sealed quartz tube with $\mathrm{CuO}$ and $\mathrm{Ag}$ powder. The quartz tubes had been previously baked at $950^{\circ} \mathrm{C}$ to eliminate possible organic matter. The $\mathrm{CO}_{2}$ produced was then reduced to graphite by adding excess $\mathrm{H}_{2}$ and using cobalt as a catalyst. The resultant mixture of graphite and cobalt was pressed into aluminium cathodes and retained in a vacuum until measurement (Santos Arevalo et al., 2009).
The PCM2 site had little organic material suitable for radiocarbon dating: no materials from short-lived organisms materials were recovered from the excavations, and the only charcoal of sufficient size were obtained from cut $C$ level 12/13. AMS radiocarbon ages are reported in conventional radiocarbon years (Stuiver and Polach, 1977) and calibrated using Calib 7.1 with Intcal'13 (Reimer et al., 2013) in cal. BC (2 $\sigma$ uncertainty) and as BP (Table 4).

Anthracological analysis was performed on the charcoal fragments after removal of the samples for AMS-radiocarbon dating. The small size and poor preservation of the charcoal samples limited the anthracological determinations to angiosperm, and in some cases the proposal of a taxon (Table 4 ).

\section{Indirect dating}

Ideally, evidence should be combined from the excavations of several well-dated sites that contained beads, pendants or charm-assemblages made from variscite. Unfortunately, accurate identification of bead mineralogy is lacking for most 'green bead' contexts in Iberia, where many green minerals other than variscite were used for beadmaking. To realistically produce a chronological framework for variscite consumption we need first to identify bead mineralogy.

The mineralogical classification of beads by means of portable analytical devices is not straightforward and deserves a full-length paper of its own. However, we have developed a simplified approach for the purpose of helping to evaluate bead chronologies. This methodology includes mineralogical identification of beads (1392 samples from 42 different sites along the Iberian Meseta and Atlantic Façade) based on the chemical composition using an Oxford Instrument XMET-7500 portable $\mathrm{X}$-ray spectrometer with a Rh tube, a silicon drift detector (SDD), and an automatic 5-position filter changer.

The identification of aluminophosphate is relatively straightforward based on Al-to-P atomic ratios. X-ray diffraction has confirmed variscite as the main crystallographic phase in almost all samples, either geological or bead-worked, with an Al-to-P atomic ratio in the compositional range of variscite $\left[\left[\mathrm{MPO}_{4} \cdot 2 \mathrm{H}_{2} \mathrm{O}\right]\right.$, where $\mathrm{M}=\mathrm{Al}^{3+}, \mathrm{Fe}^{3+}, \mathrm{Cr}^{3+}, \mathrm{V}^{3+}$ (Larsen, 1942)], from $\sim 1$ to 1.8 (refer to Odriozola et al., 2010, and Odriozola, 2014). Thus, here we use the Al-to-P atomic ratio as an indicator of variscite as the raw material of beads. Nevertheless, turquoise, crandallite or aheylite may occur separately or as minor crystallographic phases together with the variscite (Larsen, 1942). In these cases, the Al-to-P atomic ratios need to be combined with $\mathrm{Ca}, \mathrm{Cu}$ and $\mathrm{Fe}$ values to differentiate between minerals.

Differentiating green stones formed by sheet silicates, e.g., micas, talc-steatite, chlorite and serpentine, is more complicated. We conservatively classified beads as aluminophosphate, K-aluminosilicates, Mg-aluminosilicates, Mg-silicates or other silicates, based on their major element composition obtained by XRF: dominant $\mathrm{P}+\mathrm{Al}=$ aluminophosphate; dominant $\mathrm{K}+\mathrm{Al}+\mathrm{Si}=\mathrm{K}$-aluminosilicate; 
Table 4

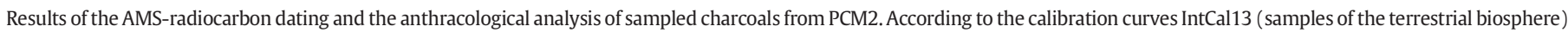
of Reimer et al. (2013), and using CALIB rev 7.1 (Stuiver and Reimer, 1993) programme.

\begin{tabular}{|c|c|c|c|c|c|c|c|}
\hline Lab. code & Specie & Sample & Context & Cut & Unit & Radiocarbon date & Calibrated date $(2 \sigma)$ \\
\hline CNA-2144 & - & Charcoal & PCM2 & $\mathrm{C}$ & 12 & $5950 \pm 40$ & 4033-4727 BC \\
\hline CNA-2145 & angiosperma & Charcoal & PCM2 & $\mathrm{C}$ & $12 / 13$ & $2215 \pm 35$ & $379-198$ BC \\
\hline CNA-2146 & Cf. Cistus sp. & Charcoal & PCM2 & $\mathrm{C}$ & 12 & $1010 \pm 35$ & AD 969-1152 \\
\hline CNA-2147 & Cf. Cistus sp., Cf. Pistacia lentiscus & Charcoal & PCM2 & $\mathrm{C}$ & 12 & $585 \pm 35$ & AD 1298-1417 \\
\hline CNA-2148 & Cf. Quercus suber & Charcoal & PCM2 & $\mathrm{C}$ & 13 & $6205 \pm 40$ & $5295-5051 \mathrm{BC}$ \\
\hline
\end{tabular}

dominant $\mathrm{Mg}+\mathrm{Al}+\mathrm{Si}=\mathrm{Mg}$-aluminosilicate; dominant $\mathrm{Mg}+\mathrm{Si}=$ $\mathrm{Mg}$-silicate. This methodology appears adequate for the purposes of this work, where the objective is to evaluate whether green beads are made from variscite or another greenstone.

\section{Results}

\section{Direct dating}

The AMS radiocarbon dating indicates a palimpsest of organic remains at the base of cut $C$ in the Neolithic (CNA 2144, 2148), Iron Age (CNA 2145), and Mediaeval periods (CNA 2146, 2147). The quantitative OSL results from fills indicate an accumulation of deposits in cut $D$ and lower cut B in the late 18th to early 19th centuries AD (ITNLUM 696, 697 ) and in the late 19th century in upper cut B (ITNLUM 699, 701) (Tables 3a and 3b). In our study, profiling was solely conducted in the laboratory, and thus was not able to inform the sampling strategy (c.f. Burbidge et al., 2008; Sanderson and Murphy, 2009); instead, it was applied in parallel with quantitative dating to aid in the interpretation of fill phases and the intensity of accumulation mechanisms that operated during the infill of the pit, and to evaluate the relations between the sediment layers from around the site that were not amenable to sampling for quantitative analysis (e.g., Odriozola et al., 2014). A frequency plot of the profiling results ( $f_{p}$, Fig. 5 ) shows how the mineral grains in most of the sampled layers were last exposed to light at $\sim 7 \mathrm{ka}$ (Neolithic), $0.6 \mathrm{ka}$ (late Mediaeval) and $0.12 \mathrm{ka}$ (Post Mediaeval). These phases correspond with the quantitative results obtained by OSL or AMS radiocarbon dating. Thus, many profiling samples that are out of stratigraphic sequence appear to contain redeposited material from the earlier phases of activity at the site, in which the OSL signal has not been reset. Such records are still useful in the interpretation of the history of the site, even though they have been removed from their original context, in the same manner as a survey or recovery of redeposited potsherds (e.g., Deckers et al., 2005; Burbidge et al., 2014).

The OSL profiling results (Fig. 5) through the stratigraphy of cut B exhibit two phases of elevated semi-quantitative age values, from samples taken in the more stony layers $(120-70$ and $35-25 \mathrm{~cm})$. These are considered indicative of redeposition without (complete) liberation of the trapped charge that is the source of the OSL signal, and hence of rapid redeposition. The quantitative and semi-quantitative results from less stony layers associated with these, either immediately below or interleaved at approximately the same depth, indicate that their accumulation in their present location corresponds with early and late 19th century infill phases. The results from the first phase $(120-70 \mathrm{~cm})$ are scattered, e.g., the difference between the results from the two aliquots measured per sample is large relative to the geometric average value that is indicated by the trend line in Fig. 5; however, many of the semi-quantitative age values approximate that of the reproducible (tightly grouped pair) from the sample at the base of cut B (at $145 \mathrm{~cm}$ ). This profiling sample, and one of the samples from cut $C$, both indicate a late Mediaeval accumulation age contemporaneous with the youngest AMS radiocarbon result from cut C (CNA 2147). The other profiling sample from cut $\mathrm{C}$ provided results that are consistent with the oldest, Neolithic, AMS radiocarbon ages (CNA 2144, 2148).

The late 19th century OSL age likely relate to soundings made in 1883 by the Mina de Cobre Santo Tomás, during the 'copper fever'
(Pérez Macías, 2008, after Jubes and Carbonell, 1920). However, fills in the lower layers in cut $B$ and the tailings in cut $D$ unit 3, both relate to an earlier phase of accumulation.

The mixture of charcoals from different periods in the same unit, the base level (12/13), indicates phases of repeated use of the cut $C$ space, until the Mediaeval period. This is also reflected by the semiquantitative OSL results from the bases of cut $C$ and cut $B$. The space surrounding the void created by the first miners was last used $\sim 600$ years ago (bonfires at the border of the pit). PCM2 is in the middle of a copper mining belt of the Ossa Morena Zone, which has been exploited since the Copper Age and was reopened at the end of the 19th century with the arrival of British mining companies.

\section{Indirect dating}

We have developed a new dataset of dated sites, combined with a bead mineralogical classification (Tables 1 and 5), which creates an ideal framework for the analysis of variscite consumption during the Late Prehistory across Iberia. Most of the contexts are burials, though the Zambujal and Penedo do Lexim sites also contain evidence for prolonged domestic occupation (Jiménez Gómez, 1995; Sousa, 2010). If the direct dating of mine contexts has limitations inherent to a continued use of the space, the dating of bead burial contexts (necropolis or settlements) is subject to difficulties of association. Most of the inventoried variscite adornments were collected in early archaeological excavations, without well-defined stratigraphic contexts. However, several bead consumption trends are evident.

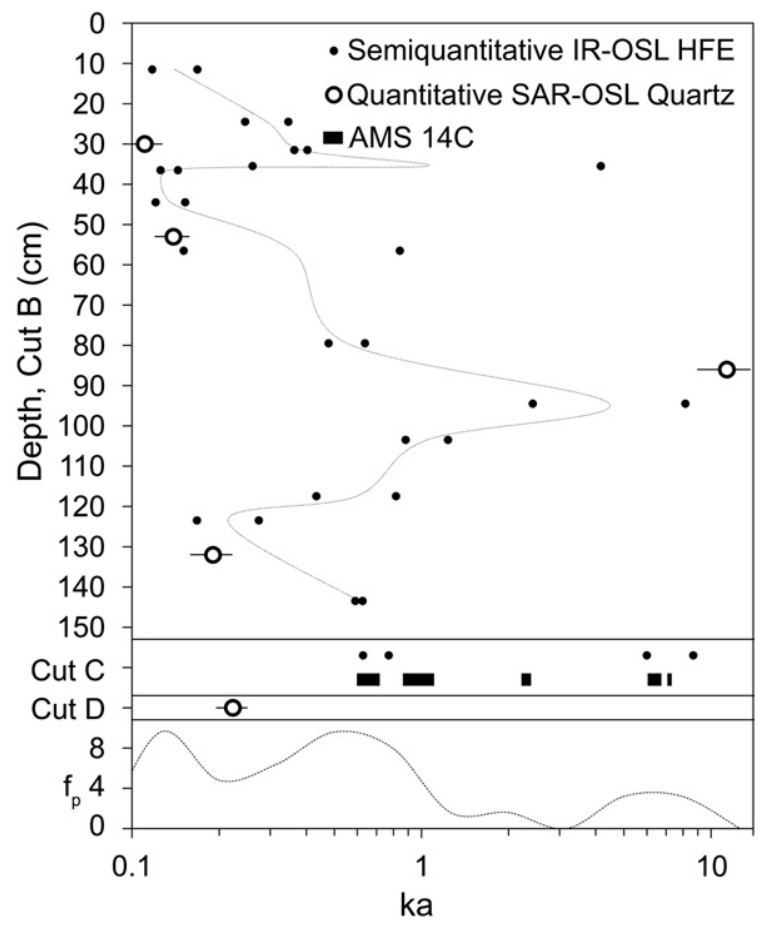

Figure 5. Chronological results from PCM2; note log time axis. 
Table 5

Studied sites with available radiocarbon ages. Calibrated ages with $2 \sigma$ uncertainty.

\begin{tabular}{|c|c|c|c|c|c|c|}
\hline \multirow[t]{2}{*}{ Lab. code } & \multirow[t]{2}{*}{ Site } & \multirow{2}{*}{$\frac{{ }^{14} \mathrm{C} \text { age }}{\mathrm{yr} \mathrm{BP}}$} & \multirow{2}{*}{$\frac{\text { Uncertainty }}{+/-\mathrm{yr}}$} & \multirow{2}{*}{$\frac{\text { Calibrated age }}{\mathrm{yr} B C}$} & \multirow{2}{*}{$\frac{\delta^{13} \mathrm{C}}{\text { per mil }}$} & \multirow[t]{2}{*}{ Reference } \\
\hline & & & & & & \\
\hline Beta-83084 & ALDEAGORDILLO & 4320 & 70 & $3325-2698$ & 0 & Fabián García (2006) \\
\hline GrN-19168 & ALDEAGORDILLO & 4115 & 20 & $2859-2581$ & 0 & Fabián García (2006) \\
\hline Beta-83085 & ALDEAGORDILLO & 4100 & 80 & $2879-2483$ & 0 & Fabián García (2006) \\
\hline Beta-194313 & ANTA DA HORTA & 4480 & 40 & $3348-3026$ & -19.7 & Oliveira (2010) \\
\hline ICEN-1264 & ANTA DAS CASTELHANAS & 6360 & 110 & $5524-5054$ & 0 & Oliveira (2000) \\
\hline Beta-243693 & ANTA GRANDE DE ZAMBUJEIRO (corridor) & 3910 & 40 & $2549-2234$ & 0 & Soares and SIlva (2010) \\
\hline Beta-123363 & CABEÇO DA ARRUDA I & 4370 & 70 & $3332-2883$ & 0 & Waterman (2012) \\
\hline Beta-132975 & CABEÇO DA ARRUDA I & 4240 & 50 & 2999-2635 & 0 & Waterman (2012) \\
\hline GrN-5110 & CARAPITO 1 & 4850 & 40 & $3707-3528$ & 0 & Senna-Martínez and Quintã Ventura (2000) \\
\hline OxA-3733 & CARAPITO 1 & 5125 & 70 & $4052-3712$ & 0 & Senna-Martínez and Quintã Ventura (2000) \\
\hline TO-3336 & CARAPITO 1 & 5120 & 40 & $3990-3798$ & 0 & Senna-Martínez and Quintã Ventura (2000) \\
\hline OxA-5506 & CASA DA MOURA & 4600 & 90 & $3631-3030$ & 0 & Cardoso et al. (1996) \\
\hline TO-953 & CASA DA MOURA & 5990 & 60 & $5019-4725$ & -19.6 & Cardoso et al. (1996) \\
\hline TO-2092 & CASA DA MOURA & 4850 & 100 & $3933-3372$ & -19.3 & Cardoso et al. (1996) \\
\hline TO-2093 & CASA DA MOURA & 5070 & 70 & 4031-3702 & -19.2 & Cardoso et al. (1996) \\
\hline TO-2094 & CASA DA MOURA & 5020 & 70 & $3960-3663$ & -19.6 & Cardoso et al. (1996) \\
\hline ICEN-802 & CASA DA MOURA (1A) & 6100 & 70 & $5217-4841$ & 0 & Cardoso et al. (1996) \\
\hline Beta-68667 & CASTILLO DE ALANGE (c/ Umbria 3/ N. II) & 3080 & 90 & 1520-1056 & 0 & Pavón Soldevila (1994) \\
\hline CNA-346 & CASULLO & 4410 & 50 & $3330-2909$ & 0 & Linares Catela and García Sanjuán, (2010) \\
\hline Beta-277240 & CHOUSA NOVA & 5450 & 40 & 4359-4237 & 0 & Dominguez Bella and Bóveda (2011) \\
\hline UBAR-593 & COVA DA MOURA & 4715 & 50 & $3634-3372$ & 0 & Silva (2003) \\
\hline UBAR-536 & COVA DA MOURA & 3950 & 60 & 2619-2213 & 0 & Silva (2003) \\
\hline ICEN-1040 & DOLMEN DA PEDRA BRANCA (chamber) & 4620 & 60 & $3628-3106$ & -19.7 & Soares (2010) \\
\hline ICEN-1041 & DOLMEN DA PEDRA BRANCA (corridor) & 4120 & 60 & $2880-2497$ & -20.06 & Soares (2010) \\
\hline Beta-80602 & DOLMEN DE ALBERITE & 5320 & 70 & 4327-3991 & 0 & Sttip and Tamers (1996) \\
\hline Beta-80600 & DOLMEN DE ALBERITE & 5110 & 140 & $4245-3641$ & 0 & Sttip and Tamers (1996) \\
\hline Beta-80598 & DOLMEN DE ALBERITE & 5020 & 70 & $3960-3663$ & 0 & Sttip and Tamers (1996) \\
\hline Poz-55021 & EL GUIJO & 4695 & 35 & $3629-3370$ & 0 & Villalobos García (2014) \\
\hline Teledyne 19080 & EL POZUELO (tomb 6) & 3580 & 120 & $2283-1625$ & 0 & Linares Catela and García Sanjuán (2010) \\
\hline GrN-18875 & EL TOMILLAR & 3925 & 40 & $2563-2291$ & 0 & Fabián García (2006) \\
\hline GrN-18669 & FUENTEPECINA II & 5375 & 45 & $4333-4056$ & 0 & Delibes de Castro and Rojo Guerra (1997) \\
\hline GrN-16073 & FUENTEPECINA II & 5170 & 100 & 4239-3714 & 0 & Delibes de Castro and Rojo Guerra (1997) \\
\hline Beta-176899 & HERDADE DOS CEBOLINHOS (ANTA 2/ chamber) & 3900 & 40 & $2480-2212$ & 0 & Gonçalves (2003) \\
\hline Beta-177471 & HERDADE DOS CEBOLINHOS (ANTA 2) & 3840 & 40 & $2461-2154$ & 0 & Gonçalves (2003) \\
\hline Beta-121143 & LA PIJOTILLA (T3 UE 15) & 4130 & 40 & $2872-2581$ & 0 & Odriozola et al. (2008) \\
\hline ITN A6/209 & LA PIJOTILLA (T3/ layer 16/ vessel 15) & 2716 & 96 & $1188-561$ & 0 & Odriozola et al. (2008) \\
\hline CNA-034 & LA PIJOTILLA (T3/ layer 18) & 4168 & 55 & $2890-2585$ & 0 & Odriozola et al. (2008) \\
\hline UGAMS 8455 & LAPA DA RAINHA & 4080 & 25 & $2851-2498$ & 0 & Waterman (2012) \\
\hline GrN-5628 & LAPA DO BUGIO & 4850 & 45 & $3711-3523$ & 0 & Silva and Wasterlain (2010) \\
\hline OxA-5507 & LAPA DO BUGIO & 4420 & 110 & $3495-2780$ & 0 & Silva and Wasterlain (2010) \\
\hline Beta-142035 & LAS MINITAS (tomb 15) & 3430 & 50 & $1881-1628$ & 0 & Pavón Soldevila (1994) \\
\hline ICEN-674 & LECEIA & 4370 & 60 & $3326-2888$ & 0 & Cardoso (2014) \\
\hline Wk-34424 & LECEIA & 3833 & 26 & $2455-2155$ & 0 & Cardoso (2014) \\
\hline ICEN-95 & LECEIA (C2) & 4370 & 60 & $3326-2888$ & 1.34 & Cardoso (2014) \\
\hline ICEN-89 & LECEIA (C2) & 4200 & 70 & $2915-2579$ & -19.91 & Cardoso (2014) \\
\hline ICEN-92 & LECEIA (C2) & 4120 & 80 & $2887-2489$ & -24.56 & Cardoso (2014) \\
\hline ICEN-102 & LECEIA (C2) & 3970 & 70 & $2838-2210$ & 1.68 & Cardoso (2014) \\
\hline ICEN-1217 & LECEIA (C2) & 4020 & 80 & $2868-2307$ & -22.64 & Cardoso (2014) \\
\hline ICEN-1220 & LECEIA (C2) & 4030 & 70 & $2867-2348$ & -20.05 & Cardoso (2014) \\
\hline ICEN-737 & LECEIA (C2) & 3920 & 70 & 2579-2155 & -19.56 & Cardoso, 2014) \\
\hline ICEN-315 & LECEIA (C2) & 3730 & 170 & 2618-1668 & -21.19 & Cardoso (2014) \\
\hline ICEN-1213 & LECEIA (C2) & 3970 & 70 & $2838-2210$ & -23.21 & Cardoso (2014) \\
\hline ICEN-1218 & LECEIA (C2) & 3910 & 60 & 2567-2206 & -23.27 & Cardoso (2014) \\
\hline ICEN-1211 & LECEIA (C2) & 3900 & 80 & $2578-2141$ & -25.05 & Cardoso (2014) \\
\hline ICEN-1215 & LECEIA (C2) & 3900 & 70 & $2571-2150$ & -20.9 & Cardoso (2014) \\
\hline ICEN-1216 & LECEIA (C2) & 3880 & 80 & $2572-2136$ & -21.22 & Cardoso (2014) \\
\hline ICEN-1214 & LECEIA (C2) & 3840 & 110 & 2578-1972 & -26.21 & Cardoso (2014) \\
\hline ICEN-314 & LECEIA (C2) & 3770 & 130 & $2571-1783$ & -25.75 & Cardoso (2014) \\
\hline ICEN-91 & LECEIA (C3) & 4130 & 60 & $2883-2501$ & -20 & Cardoso (2014) \\
\hline ICEN-673 & LECEIA (C3) & 4130 & 100 & $2915-2465$ & -24.9 & Cardoso (2014) \\
\hline ICEN-675 & LECEIA (C3) & 4100 & 90 & 2890-2469 & -25.4 & Cardoso (2014) \\
\hline ICEN-1173 & LECEIA (C3) & 4170 & 50 & $2890-2589$ & -20.5 & Cardoso (2014) \\
\hline ICEN-1175 & LECEIA (C3) & 4090 & 80 & $2876-2476$ & -19.85 & Cardoso (2014) \\
\hline ICEN-1176 & LECEIA (C3) & 4090 & 60 & $2872-2489$ & -20.02 & Cardoso (2014) \\
\hline ICEN-1177 & LECEIA (C3) & 4050 & 50 & $2858-2469$ & -21.12 & Cardoso (2014) \\
\hline LY-4205 & LECEIA (C3) & 4030 & 120 & $2889-2210$ & -21.2 & Cardoso (2014) \\
\hline ICEN-1160 & LECEIA (C4) & 4630 & 60 & $3631-3114$ & 0 & Cardoso (2014) \\
\hline ICEN-312 & LECEIA (C4) & 4530 & 100 & $3515-2924$ & 0 & Cardoso (2014) \\
\hline ICEN-316 & LECEIA (C4) & 4520 & 70 & $3496-2940$ & 0 & Cardoso (2014) \\
\hline ICEN-312 & LECEIA (C4) & 4530 & 100 & $3515-2924$ & -20.22 & Cardoso (2014) \\
\hline ICEN-313 & LECEIA (C4) & 4520 & 130 & $3626-2903$ & -22 & Cardoso (2014) \\
\hline ICEN-316 & LECEIA (C4) & 4520 & 70 & $3496-2940$ & -22.02 & Cardoso (2014) \\
\hline ICEN-1275 & LECEIA (EN) & 3950 & 90 & 2858-2149 & 0 & Cardoso (2014) \\
\hline
\end{tabular}


Table 5 (continued)

\begin{tabular}{|c|c|c|c|c|c|c|}
\hline \multirow[t]{2}{*}{ Lab. code } & \multirow[t]{2}{*}{ Site } & \multirow{2}{*}{$\frac{{ }^{14} \mathrm{C} \text { age }}{\mathrm{yr} \mathrm{BP}}$} & \multirow{2}{*}{$\frac{\text { Uncertainty }}{+/-\mathrm{yr}}$} & \multirow{2}{*}{$\frac{\text { Calibrated age }}{\mathrm{yr} \mathrm{BC}}$} & \multirow{2}{*}{$\frac{\delta^{13} \mathrm{C}}{\text { per mil }}$} & \multirow[t]{2}{*}{ Reference } \\
\hline & & & & & & \\
\hline ICEN-1241 & LECEIA (EN) & 3950 & 90 & $2852-2149$ & 0 & Cardoso (2014) \\
\hline Beta-260295 & LECEIA (EN) & 3840 & 40 & $2461-2154$ & 0 & Cardoso (2014) \\
\hline Beta-260296 & LECEIA (EN) & 3980 & 40 & $2617-2347$ & 0 & Cardoso (2014) \\
\hline Sac-1317 & LECEIA (FM) & 4220 & 50 & $2914-2634$ & 0 & Cardoso (2014) \\
\hline Sac-1317 & LECEIA (FM) & 4220 & 50 & 2914-2634 & 0 & Cardoso (2014) \\
\hline Beta-260297 & LECEIA (FM) & 4140 & 40 & $2876-2585$ & 0 & Cardoso (2014) \\
\hline Beta-260299 & LECEIA (FM) & 4100 & 40 & $2869-2498$ & 0 & Cardoso (2014) \\
\hline Sac-1317 & LECEIA (FM) & 4220 & 40 & $2907-2675$ & 0 & Cardoso (2014) \\
\hline Beta-260297 & LECEIA (FM) & 4140 & 40 & $2876-2585$ & 0 & Cardoso (2014) \\
\hline Beta-260299 & LECEIA (FM) & 4100 & 40 & $2869-2498$ & 0 & Cardoso (2014) \\
\hline ICEN-1160 & LECEIA (layer 4) & 4630 & 45 & $3624-3139$ & -21.81 & Cardoso (2014) \\
\hline ICEN-1161 & LECEIA (layer 4) & 4440 & 50 & $3336-2924$ & -23.39 & Cardoso (2014) \\
\hline ICEN-1159 & LECEIA (layer 4) & 4430 & 50 & 3334-2919 & -21.35 & Cardoso (2014) \\
\hline ICEN-1158 & LECEIA (layer 4) & 4320 & 50 & $3090-2877$ & -21.45 & Cardoso (2014) \\
\hline Beta-185650 & LOS GABRIELES (dolmen 4/ chamber 2) & 3700 & 50 & 2273-1945 & 0 & Linares Catela and García Sanjuán (2010) \\
\hline Beta-185648 & LOS GABRIELES (dolmen 4/ chamber 3) & 3850 & 40 & $2460-2205$ & 0 & Linares Catela and García Sanjuán (2010) \\
\hline Beta-185649 & LOS GABRIELES (dolmen 4/ chamber 4) & 3920 & 50 & $2567-2213$ & 0 & Linares Catela and García Sanjuán (2010) \\
\hline $\mathrm{I}-16150$ & LOS ITUEROS & 4120 & 130 & $3011-2300$ & 0 & Fabián García (2006) \\
\hline I-83088 & LOS ITUEROS & 3960 & 90 & $2857-2155$ & 0 & Fabián García (2006) \\
\hline I-16149 & LOS ITUEROS & 3850 & 100 & $2574-2028$ & 0 & Fabián García (2006) \\
\hline OxA-5535 & MARMOTA 2 & 4600 & 55 & $3520-3104$ & 0 & Gonçalves (2002) \\
\hline Sac-2122 & MOITA DA LADRA & 3700 & 50 & 2273-1945 & 0 & Cardoso and Caninas (2010) \\
\hline Sac- 2123 & MOITA DA LADRA & 3700 & 50 & 2273-1945 & 0 & Cardoso and Caninas (2010) \\
\hline Sac-2370 & MOITA DA LADRA & 3930 & 80 & $2831-2146$ & 0 & Cardoso and Caninas (2010) \\
\hline Sac-2371 & MOITA DA LADRA & 3810 & 60 & 2463-2049 & 0 & Cardoso and Caninas (2010) \\
\hline ICEN-957 & OLIVAL DA PEGA 2B (phase VF1/OP4) & 4130 & 60 & $2883-2501$ & 0 & Gonçalves (2002) \\
\hline ICEN-956 & OLIVAL DA PEGA 2B (phase VF3/OP2) & 4180 & 80 & $2918-2497$ & 0 & Gonçalves (2002) \\
\hline ICEN-955 & OLIVAL DA PEGA 2B (phase VF3/OP3) & 4290 & 100 & $3328-2584$ & 0 & Gonçalves (2002) \\
\hline Sac-1556 & PAIMOGO & 4259 & 90 & $3262-2575$ & 0 & Gonçalves (2002) \\
\hline UBAR-539 & PAIMOGO & 4139 & 90 & $2900-2488$ & 0 & Gonçalves (2002) \\
\hline Beta-186854 & PENEDO DE LEXIM (locus 1 / layer 19) & 4080 & 50 & $2865-2483$ & -20.5 & Sousa (2010) \\
\hline Beta-142451 & PENEDO DE LEXIM (locus 1/ layer 19) & 3820 & 40 & $2456-2142$ & 0 & Sousa (2010) \\
\hline Sac-2067 & PENEDO DE LEXIM (locus 1 / layer 19) & 3820 & 50 & $2458-2140$ & -20.74 & Sousa $(2010)$ \\
\hline Sac-2156 & PENEDO DE LEXIM (locus 1) & 3640 & 40 & 2291-2036 & 0 & Sousa (2010) \\
\hline Beta-186855 & PENEDO DE LEXIM (locus 3/ layer 19) & 3760 & 40 & 2291-2036 & -19.6 & Sousa (2010) \\
\hline Beta-175775 & PENEDO DE LEXIM (locus 3b/ layer 10) & 4080 & 40 & $2862-2489$ & -21.2 & Sousa (2010) \\
\hline Sac-2158 & PENEDO DE LEXIM (locus 3b/layer 7) & 3880 & 60 & $2550-2148$ & 0 & Sousa (2010) \\
\hline Sac-2069 & PENEDO DE LEXIM (locus 3b/ layer 7b) & 3930 & 30 & $2550-2300$ & -21.2 & Sousa (2010) \\
\hline Sac-2168 & PENEDO DE LEXIM (locus 5/ layer 8) & 3760 & 50 & $2341-2026$ & 0 & Sousa (2010) \\
\hline Beta-175774 & PENEDO DE LEXIM (locus3b/ layer 16) & 4100 & 40 & $2869-2498$ & -20.2 & Sousa (2010) \\
\hline W-656 & PENHA VERDE & 3420 & 200 & $2289-1233$ & 0 & Cardoso (2010) \\
\hline W-656 & PENHA VERDE & 3420 & 200 & $2289-1233$ & 0 & Cardoso (2010) \\
\hline Beta-260300 & PENHA VERDE (22/064) & 4000 & 40 & $2830-2369$ & 0 & Cardoso (2010) \\
\hline Beta-276400 & PENHA VERDE (ditch HUT 2) & 3970 & 40 & $2578-2346$ & 0 & Cardoso (2010) \\
\hline Beta-276399 & PENHA VERDE (HUT 1) & 3890 & 40 & $2473-2211$ & 0 & Cardoso (2010) \\
\hline Beta-296578 & PENHA VERDE (HUT 2) & 3700 & 30 & 2198-1981 & 0 & Cardoso (2010) \\
\hline Beta-296580 & PENHA VERDE (HUT 3) & 3680 & 40 & 2196-1948 & 0 & Cardoso (2010) \\
\hline Beta-276398 & PENHA VERDE (pavement HUT 2) & 3830 & 40 & $2458-2148$ & 0 & Cardoso (2010) \\
\hline Beta-327750 & PERDIGÕES (Tomb 1) & 4030 & 40 & $2834-2468$ & 0 & Valera et al. (2014) \\
\hline Beta-327748 & PERDIGÕES (Tomb 1) & 4060 & 30 & $2839-2483$ & 0 & Valera et al. (2014) \\
\hline Beta-327747 & PERDIGÕES (Tomb 1) & 4130 & 30 & $2871-2583$ & 0 & Valera et al. (2014) \\
\hline Beta-308789 & PERDIGÕES (Tomb 2) & 3840 & 30 & $2456-2202$ & 0 & Valera et al. (2014) \\
\hline Beta-308791 & PERDIGÕES (Tomb 2) & 4090 & 30 & 2859-2499 & 0 & Valera et al. (2014) \\
\hline Beta-308792 & PERDIGÕES (Tomb 2) & 3890 & 30 & $2468-2291$ & 0 & Valera et al. (2014) \\
\hline Beta-308793 & PERDIGÕES (Tomb 2) & 3970 & 30 & $2574-2350$ & 0 & Valera et al. (2014) \\
\hline OxA-5533 & POÇO VELHO & 4245 & 55 & $3010-2634$ & 0 & Gonçalves (2008) \\
\hline OxA-5532 & POÇO VELHO & 4090 & 55 & $2871-2490$ & 0 & Gonçalves (2008) \\
\hline Beta-244396 & POÇO VELHO (F-2) & 4090 & 40 & $2865-2493$ & -19.1 & Gonçalves (2008) \\
\hline Beta-245137 & POÇO VELHO (F-2) & 4030 & 40 & $2834-2468$ & -10.2 & Gonçalves (2008) \\
\hline Beta-244397 & POÇO VELHO (F-2) & 3920 & 40 & $2562-2289$ & -9.8 & Gonçalves (2008) \\
\hline Beta-244394 & POÇO VELHO (F-3) & 4520 & 40 & $3360-3097$ & -19.1 & Gonçalves (2008) \\
\hline Beta-245138 & POÇO VELHO (F-3) & 4500 & 40 & $3355-3034$ & -19.1 & Gonçalves (2008) \\
\hline Beta-244395 & POÇO VELHO (F-3) & 4030 & 40 & $2834-2468$ & -18.5 & Gonçalves (2008) \\
\hline OxA-5533 & POÇO VELHO (SIF) & 4245 & 55 & $3010-2634$ & -19.4 & Gonçalves (2008) \\
\hline Beta-244393 & POÇO VELHO (SIF) & 4160 & 50 & $2886-2585$ & -19.1 & Gonçalves (2008) \\
\hline Beta-178464 & POÇO VELHO (SIF) & 4150 & 40 & $2879-2589$ & -19.3 & Gonçalves (2008) \\
\hline Beta-244390 & POÇO VELHO (SIF) & 4150 & 40 & $2879-2589$ & 0 & Gonçalves (2008) \\
\hline OxA-5532 & POÇO VELHO (SIF) & 4090 & 55 & $2871-2490$ & -19.6 & Gonçalves (2008) \\
\hline Beta-244392 & POÇO VELHO (SIF) & 3970 & 40 & $2578-2346$ & -18.8 & Gonçalves (2008) \\
\hline Beta-178463 & POÇO VELHO (SIF) & 3960 & 40 & $2575-2341$ & -19.7 & Gonçalves (2008) \\
\hline Beta-244391 & POÇO VELHO (SIF) & 48090 & 1200 & - & -20.1 & Gonçalves (2008) \\
\hline $\mathrm{H}-2049 / 148$ & PRAIA DAS MAÇAS (chamber) & 4260 & 60 & $3076-2637$ & 0 & Gonçalves (2002) \\
\hline H-2048/1458 & PRAIA DAS MAÇAS (chamber) & 3650 & 60 & $2200-1884$ & 0 & Gonçalves (2002) \\
\hline OxA-5509 & PRAIA DAS MAÇAS (west chamber) & 4410 & 75 & $3338-2903$ & 0 & Gonçalves (2002) \\
\hline OxA-5510 & PRAIA DAS MAÇAS (west chamber) & 4395 & 60 & $3331-2899$ & 0 & Gonçalves, 2002) \\
\hline
\end{tabular}


Table 5 (continued)

\begin{tabular}{|c|c|c|c|c|c|c|}
\hline \multirow[t]{2}{*}{ Lab. code } & \multirow[t]{2}{*}{ Site } & \multirow{2}{*}{$\frac{{ }^{14} \mathrm{C} \text { age }}{\mathrm{yr} B P}$} & \multirow{2}{*}{$\frac{\text { Uncertainty }}{+/-\mathrm{yr}}$} & \multirow{2}{*}{$\frac{\text { Calibrated age }}{\mathrm{yr} \mathrm{BC}}$} & \multirow{2}{*}{$\frac{\delta^{13} \mathrm{C}}{\text { per mil }}$} & \multirow[t]{2}{*}{ Reference } \\
\hline & & & & & & \\
\hline Leisner \& Frreira/ 1963 & PRAIA DAS MAÇAS (west chamber) & 4160 & 110 & $3012-2467$ & 0 & Gonçalves (2002) \\
\hline Leisner \& Frreira/ 1963 & PRAIA DAS MAÇAS (west chamber) & 3650 & 100 & 2334-1706 & 0 & Gonçalves (2002) \\
\hline CNA-342 & PUERTO DE LOS HUERTOS & 4070 & 50 & $2863-2475$ & 0 & Linares Catela and García Sanjuán (2010) \\
\hline CNA-344 & PUERTO DE LOS HUERTOS & 3940 & 50 & $2572-2291$ & 0 & Linares Catela and García Sanjuán (2010) \\
\hline CNA-341 & PUERTO DE LOS HUERTOS & 3680 & 50 & $2202-1930$ & 0 & Linares Catela and García Sanjuán (2010) \\
\hline GrN-10744 & QUINTA DO ANJO (H-3) & 4040 & 70 & $2872-2351$ & 0 & Gonçalves (2002) \\
\hline OxA-5508 & QUINTA DO ANJO (H-3) & 4050 & 60 & $2866-2465$ & 0 & Gonçalves (2002) \\
\hline UBAR-629 & S. PAULO II & 3960 & 190 & $2920-1921$ & 0 & Silva (2003) \\
\hline UBAR-630 & S. PAULO II & 3870 & 70 & $2562-2139$ & 0 & Silva (2003) \\
\hline Beta-188390 & S. PEDRO DE ESTORIL 1 & 4720 & 40 & $3634-3374$ & -19 & Gonçalves (2005) \\
\hline Beta-178467 & S. PEDRO DE ESTORIL 1 & 3830 & 40 & $2458-2148$ & -19.4 & Gonçalves (2005) \\
\hline Beta-178468 & S. PEDRO DE ESTORIL 1 & 3790 & 40 & 2401-2045 & -19.6 & Gonçalves (2005) \\
\hline UGAMS 8455 & THOLOS DA BORRACHEIRA & 4420 & 25 & 3309-2923 & 0 & Waterman (2012) \\
\hline UGAMS 8454 & THOLOS DA BORRACHEIRA & 3720 & 25 & $2198-2035$ & 0 & Waterman (2012) \\
\hline Ua-10831 & VALE DE RODRIGO (chamber) & 3905 & 75 & $2576-2146$ & 0 & Boaventura (2011) \\
\hline Ua-10830 & VALE DE RODRIGO (chamber) & 4905 & 60 & $3910-3532$ & 0 & Boaventura (2011) \\
\hline KIA-31381 & VALE DE RODRIGO 3 (layer 8) & 4996 & 29 & $3935-3701$ & 0 & Boaventura (2011) \\
\hline KIA-27559 & ZAMBUJAL (ant. phase 1) & 4238 & 29 & 2909-2705 & 0 & Kunst and Lutz (2011) \\
\hline KIA-7260 & ZAMBUJAL (ant. phase 1a) & 4134 & 43 & $2874-2582$ & 0 & Kunst and Lutz (2011) \\
\hline KIA-27563 & ZAMBUJAL (ant. phase 3b) & 4065 & 37 & $2854-2485$ & 0 & Kunst and Lutz (2011) \\
\hline KIA-28669 & ZAMBUJAL (ant. phase 4) & 4001 & 28 & $2574-2471$ & 0 & Kunst and Lutz (2011) \\
\hline KIA-27557 & ZAMBUJAL (ant. phase 4) & 3996 & 23 & $2571-2470$ & 0 & Kunst and Lutz (2011) \\
\hline KIA-27558 & ZAMBUJAL (phase 1) & 4129 & 31 & $2871-2582$ & 0 & Kunst and Lutz (2011) \\
\hline KIA-7259 & ZAMBUJAL (phase 1a) & 3801 & 43 & $2456-2058$ & 0 & Kunst and Lutz (2011) \\
\hline KIA-7258 & ZAMBUJAL (phase 1a) & 3891 & 43 & $2475-2209$ & 0 & Kunst and Lutz (2011) \\
\hline KIA-4509 & ZAMBUJAL (phase 1a) & 3960 & 44 & $2577-2308$ & 0 & Kunst and Lutz (2011) \\
\hline KIA-7256 & ZAMBUJAL (phase $1 \mathrm{~b}$ ) & 3951 & 55 & $2617-2236$ & 0 & Kunst and Lutz (2011) \\
\hline GrN-7009 & ZAMBUJAL (phase 1c) & 4200 & 40 & $2899-2638$ & 0 & Kunst and Lutz (2011) \\
\hline KIA-7257 & ZAMBUJAL (phase 1c) & 3836 & 39 & $2459-2153$ & 0 & Kunst and Lutz (2011) \\
\hline GrN-6671 & ZAMBUJAL (phase 2) & 4170 & 55 & $2891-2585$ & 0 & Kunst and Lutz (2011) \\
\hline GrN-7002 & ZAMBUJAL (phase 2) & 4050 & 40 & $2849-2472$ & 0 & Kunst and Lutz (2011) \\
\hline KIA-27561 & ZAMBUJAL (phase 2) & 4155 & 32 & $2878-2629$ & 0 & Kunst and Lutz (2011) \\
\hline KIA-27562 & ZAMBUJAL (phase 2) & 4049 & 25 & $2832-2486$ & 0 & Kunst and Lutz (2011) \\
\hline KN-4989 & ZAMBUJAL (phase 2) & 3917 & 50 & $2566-2212$ & 0 & Kunst and Lutz (2011) \\
\hline $\mathrm{KN}-4990$ & ZAMBUJAL (phase 2) & 3934 & 51 & $2573-2236$ & 0 & Kunst and Lutz (2011) \\
\hline $\mathrm{KN}-4988$ & ZAMBUJAL (phase 2) & 3980 & 40 & $2617-2347$ & 0 & Kunst and Lutz (2011) \\
\hline KIA-7261 & ZAMBUJAL (phase 2b/c) & 3842 & 37 & $2458-2202$ & 0 & Kunst and Lutz (2011) \\
\hline KIA-27564 & ZAMBUJAL (phase 3) & 3992 & 32 & $2578-2464$ & 0 & Kunst and Lutz (2011) \\
\hline KN-I.115 & ZAMBUJAL (phase 3/4) & 3530 & 65 & 2029-1692 & 0 & Kunst and Lutz (2011) \\
\hline GrN-7003 & ZAMBUJAL (phase 3b) & 4055 & 40 & $2851-2474$ & 0 & Kunst and Lutz (2011) \\
\hline GrN-7004 & ZAMBUJAL (phase 3b) & 3995 & 35 & $2618-2459$ & 0 & Kunst and Lutz (2011) \\
\hline GrN-7005 & ZAMBUJAL (phase 3c) & 4055 & 40 & $2851-2474$ & 0 & Kunst and Lutz (2011) \\
\hline GrN-7008 & ZAMBUJAL (phase 3c) & 3980 & 35 & $2579-2350$ & 0 & Kunst and Lutz (2011) \\
\hline GrN-6670 & ZAMBUJAL (phase $3 c / 4 a$ ) & 4150 & 105 & $3009-2464$ & 0 & Kunst and Lutz (2011) \\
\hline KIA-28668 & ZAMBUJAL (phase 4) & 3999 & 29 & $2574-2470$ & 0 & Kunst and Lutz (2011) \\
\hline GrN-7006 & ZAMBUJAL (phase 4a/c) & 4090 & 40 & $2865-2493$ & 0 & Kunst and Lutz (2011) \\
\hline GrN-6669 & ZAMBUJAL (phase 4b) & 4025 & 95 & $2874-2300$ & 0 & Kunst and Lutz (2011) \\
\hline GrN-7007C & ZAMBUJAL (phase 4b) & 3950 & 65 & $2622-2209$ & 0 & Kunst and Lutz (2011) \\
\hline GrN-6668 & ZAMBUJAL (phase 4c/d) & 3625 & 65 & 2197-1776 & 0 & Kunst and Lutz (2011) \\
\hline $\mathrm{KN}-4507$ & ZAMBUJAL (phase 5) & 3466 & 53 & 1917-1645 & 0 & Kunst and Lutz (2011) \\
\hline $\mathrm{KN}-4506$ & ZAMBUJAL (phase 5) & 3847 & 34 & $2457-2205$ & 0 & Kunst and Lutz (2011) \\
\hline KIA-27565 & ZAMBUJAL (post. phase 3b) & 4445 & 31 & $3333-2936$ & 0 & Kunst and Lutz (2011) \\
\hline KIA-27556 & ZAMBUJAL (post. phase 3b) & 3965 & 32 & $2573-2348$ & 0 & Kunst and Lutz (2011) \\
\hline KIA-27566 & ZAMBUJAL (post. phase 5) & 3467 & 36 & $1885-1692$ & 0 & Kunst and Lutz (2011) \\
\hline KIA-27641 & ZAMBUJAL (post. phase 5) & 2381 & 40 & $740-385$ & 0 & Kunst and Lutz (2011) \\
\hline
\end{tabular}

The calibrated age plotted with the mineralogical diversity of bead assemblages for each site show that variscite began in the 5th millennium BC (Fig. 5). Figure 6 shows that variscite is not the main mineral used in the 4th millennium BC and that variscite in greenstone ornaments became dominant during the 3rd millennium BC, as has previously been stated for Portuguese Estremadura (Jiménez Gómez, 1995) and the northern Spanish Meseta (Villalobos García, 2012). By the end of the 3rd millennium, the use of variscite suddenly ceases in favour of the use of green micas.

\section{Discussion}

In general, variscite was exploited for beadmaking during the Late Prehistory (Villalba et al., 2001) and during Roman times, for both beadmaking and tesselae production (Gutiérrez Pérez et al., 2015).
Weak evidence points to an occasional use during the Bronze Age (Schubart et al., 2004) and in the 18th century (García-Guinea et al., 2000). This resource was unlikely to have been exploited during the medieval times. Pico Centeno is most likely to have been exploited during the Neolithic and Roman periods, when the archaeological record indicates that variscite was used most intensively for beadmaking.

The ages for Pico Centeno's PCM2 variscite mine together with the typological and technological criteria provide strong evidence of intermittent exploitation during specific periods during Late Prehistory, the Iron Age, the Mediaeval Age, and the Modern Era.

For the Iberian Peninsula, a generalised use of variscite is known at the beginning of Late Prehistory (Villalba et al., 2001) and for Roman times (Gutiérrez Pérez et al., 2015); its use was sporadic in modern times (Garcia-Guinea et al., 2000). Metal mining was also of historical importance in Southwest Iberia, specifically at Encinasola and its 
ANTA DAS CASTELHANAS

CHOUSA NOVA

FUENTEPECINA II (SP)

DOLMEN DE ALBERITE (SP)

VALE DE RODRIGO (SP)

CARAPITO 1 (SP)

EL GUIJO

MARMOTA 2

ANTA DA HORTA

CASULLO

LAPA DO BUGIO (SP)

CASA DA MOURA (SP)

CABEÇO DE ARRUDA 1 (SP)

PAIMOGO (SP)

LA PIJOTILLA TOMB 3 (SP)

DOLMEN DA PEDRA BRANCA (SP)

ALDEAGORDILLO (SP)

LAPA DA RAINHA

QUINTA DO ANJO CAVE 3 (SP)

POÇO VELHO (SP)

EL TOMILLAR

ANTA GRANDE DE ZAMBUJEIRO (corridor)

COVA DA MOURA (SP)

PERDIGÕES TOMB 1 \& 2 (SP)

ZAMBUJAL (SP)

LECEIA (SP)

LOS ITUEROS (SP)

SÃO PAULO II (SP)

PENEDO DE LEXIM (SP)

SÃO PEDRO DE ESTORIL 1 (SP)

LOS GABRIELES (SP)

THOLOS BORRACHEIRA (SP)

PUERTO DE LOS HUERTOS (SP)

MOITA DA LADRA (SP)

PENHA VERDE (SP)

PRAIA MAÇAS (SP)

EL POZUELO (tomb 6)

LAS MINITAS (tomb 15)

FUENTE ÁLAMO (SP)

CASTILLO DE ALANGE, C/UMBRIA (SP)

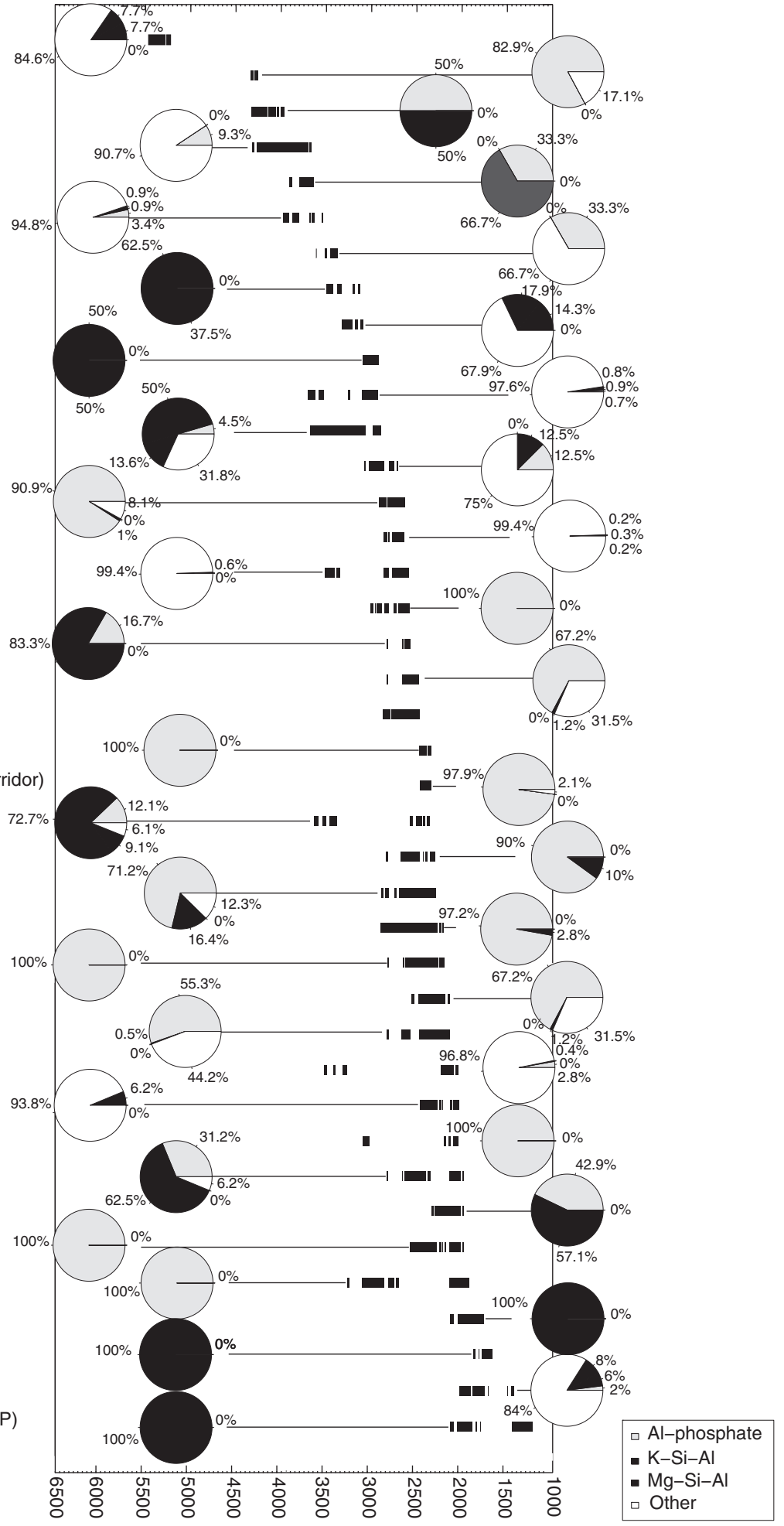

cal BC

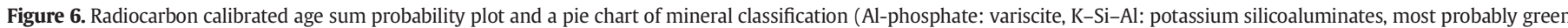
micas, $\mathrm{Mg}-\mathrm{Si}-\mathrm{Al}$ : magnesium silicates and silicoaluminates, most probably steatites and serpentinites) for studied sites.

surroundings (Pérez Macías, 2008). The 3rd century BC and 9-10th, 14th, and 18-19th centuries AD mining activities at Pico Centeno are therefore likely related to the production of metals rather than variscite.

The oldest ages recorded at Pico Centeno for Late Prehistory (53005000 and 4900-4700 BC) point to Early and Middle Neolithic exploitation. However, charcoal radiocarbon ages may be biassed towards excessive antiquity by the old wood effect, i.e., the age of the tree and/or the time between its death and its use as fuel and/or the time between its use as fuel and its deposition in the excavated context (Schiffer, 1986). The lack of recorded settlements from late 6th millennium BC in the Pico Centeno surroundings would, to a degree, support an old wood effect on the ages. Conversely, a closer examination of the available chronologies of Iberian sites would support an early exploitation of variscite, e.g., Cueva del Moro and Cueva de Chaves (Baldellou et al., 2012) and 
likely Gruta do Caldeirão (Real, 1992) during 6th millennium BC, and Chousa Nova (Dominguez-Bella and Bóveda, 2011), Dolmen de Alberite (Sttip and Tamers, 1996), or Fuentepecina II (Rojo Guerra et al., 1996; Delibes de Castro and Rojo Guerra, 1997) during the 5th millennium BC.

According to PCM2 radiocarbon ages, quarrying and spread of the green alpine jade axe around Western Europe, with its widest spread and maximum exchange intensification at $\sim 4500 \mathrm{BC}$, occurred coeval in time with the initial process of discovery, production and network exchange of variscite (Pétrequin et al., 2006) (Fig. 6 and Table 1). The main difference appears to be one of scale.

From 4500 BC onwards, mainly in the 4th and first half of 3rd millennia BC, variscite mining activity greatly increased (Blasco et al., 1992), and variscite products become conspicuous in archaeological sites of the Iberian Peninsula (Guitán Rivera and Vázquez-Varela,

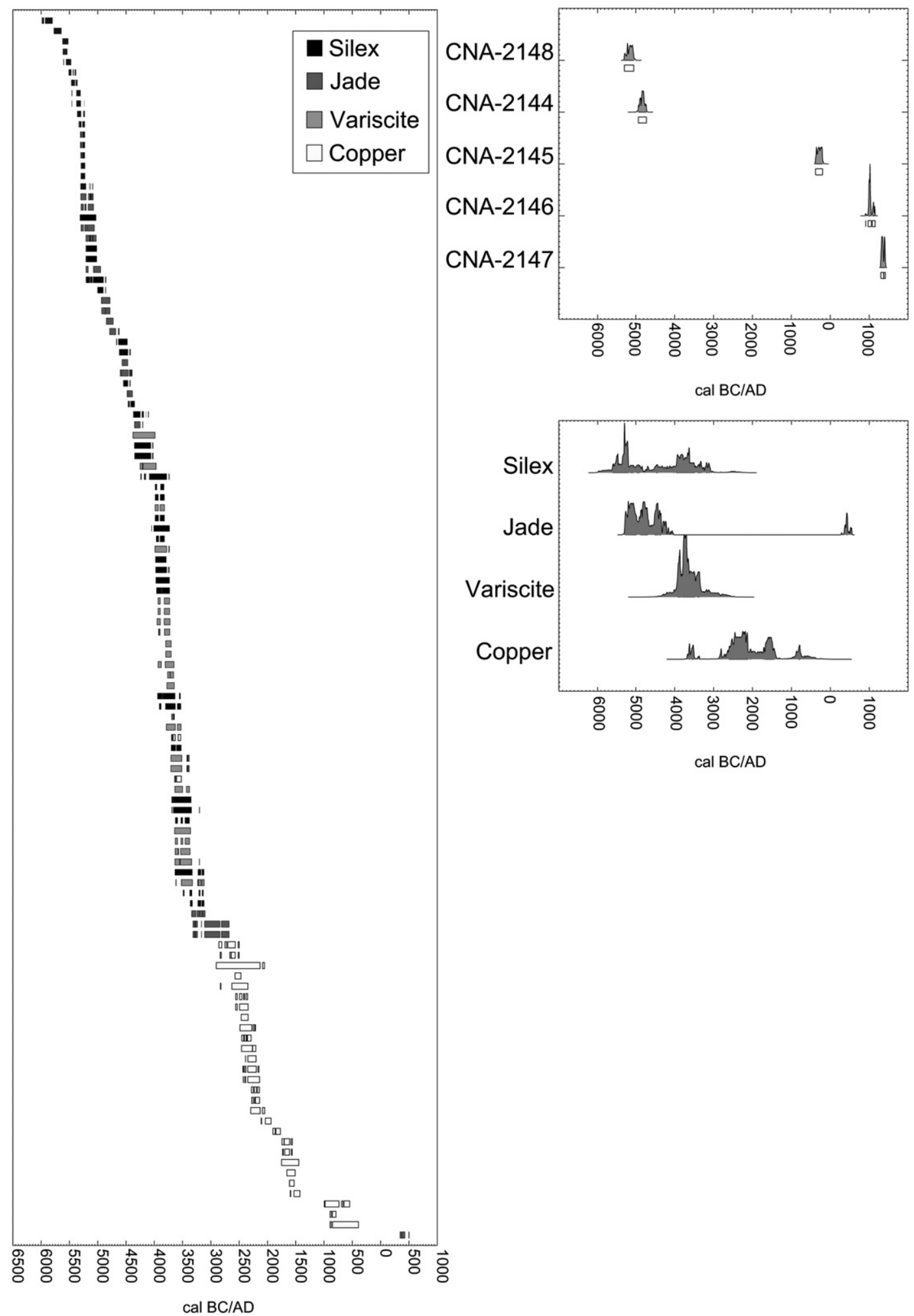

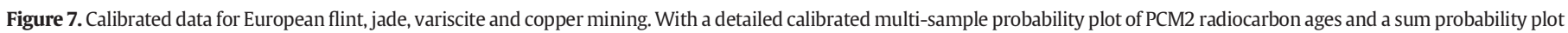
of flint, jade, variscite and copper European radiocarbon ages. 
1975; Gonçalves and Reis, 1982; Blasco et al., 1997; Bueno Ramírez et al., 2005; Costa et al., 2011; Villalobos García, 2012). Therefore, the use of variscite beads became extremely popular; achieving a period of maximum spread and use during the first half of the 3rd millennium BC, whereas the use of other green stones became rare (Fig. 7 and Table 5).

From 2500 BC onwards variscite use began to decline, but not in favour of other greenstones, the use of which had already declined in favour of variscite (Villalobos García, 2012). Rather, this coincides with increased availability of copper-based metals (Murillo-Barroso and Montero Ruiz, 2012), and new 'exotic' resources such as Asian and African Ivory (Schuhmacher et al., 2009; Schuhmacher, 2012), and Baltic and Sicilian amber (Murillo-Barroso and Martinón-Torres, 2012).

\section{Conclusions}

AMS radiocarbon and OSL dating of PCM2 indicate a long history of use, from the end of the 6th millennium BC Neolithic exploitation of variscite to the 19th century AD copper soundings made by Mina de Cobre Santo Tomás. The OSL dating indicates that fills and tailings accumulated in their present positions in the late 18th and late 19th centuries. The AMS radiocarbon dating of apparently in situ material set at the rear of the mine excavation indicated a palimpsest from the Neolithic, Iron Age and Mediaeval periods. The semi-quantitative OSL profiling results, from small samples obtained from stony layers and the remnants of excavated fills that were not amenable to sampling for fully quantitative OSL analysis, corroborate the chronological indications from both quantitative OSL and from AMS-radiocarbon. Thus, radiocarbon and OSL dating provide complementary information on different phases of site usage, which is linked by luminescence profiling.

Our new datasets support an interpretation of intermittent low intensity mining activity over a prolonged period. The intensity appears similar to that of 3rd millennium BC North Iberian copper mining, which has been calculated as 35 person-days of labour over 800 years (de Blas Cortina, 1998). The present dataset locates the beginning of variscite consumption coeval in time to the decline of jade in the 5th-4th millennium BC; the end coincides with the appearance of other signifying items in the second half of the 3rd millennium BC such as copper, ivory and extra-peninsular amber. Variscite consumption achieves its apogee in $3000 \mathrm{BC}$, when it appears in nearly every Iberian burial (Jiménez Goméz, 1995; Villalobos García, 2012).

\section{Acknowledgments}

The authors acknowledge the Ministerio de Economía y Competitividad (HAR2012-34620) for their financial support. Odriozola acknowledges Universidad de Sevilla for a postdoctoral grant. Burbidge acknowledges PTDC/AAC-AMB/121375/2010 for implementation of gamma spectrometry.

\section{Appendix A. Supplementary data}

Supplementary data to this article can be found online at http://dx. doi.org/10.1016/j.yqres.2015.11.010.

\section{References}

Acosta, P., 1995. Las culturas del neolítico y calcolítico en Andalucía Occidental. Espacio Tiempo y Forma. Serie Prehistoria y Arqueología 8, 33-80. http://dx.doi.org/10. 5944/etf +i.8.1995.4720.

Alonso, M., Edo, M., Gordo, L., Villalba, M.J., 1978. Explotación minera neolítica en Can Tintorer. Pirenae 13-14, 7-14.

Ambert, P., 2002. Utilisation préhistorique de la technique minière d'abattage au feu dans le district cuprifère de Cabrières (Hérault). Comptes Rendus Palevol 1, 711-716. http://dx.doi.org/10.1016/S1631-0683(02)00078-7.

Arribas, A., Nicolau, J., Burg, R., 1970. A new ocurrence of variscite in Spain. Lapidary Journal 107, 764
Arribas, A., Galán, E., Martín-Pozas, J.M., Nicolau, J., Salvador, P., 1971. Estudio mineralógico de la variscita de Palazuelo de las Cuevas, Zamora (España). Studia Geologica Salmanticensia 2, 115-132.

Balagny, C., 1939. Le mystere de la callais. Societé Archéologique de Nantes 79, 173-216. Baldellou, V., Utrilla Miranda, P., García-Gazólaz, J., 2012. Variscita de Can Tintorer en el Neolítico Antiguo del Valle Medio del Ebro. In: Borrell, M., Borrell, F., Bosch, J., Clop, X., Molist, M. (Eds.), Actes Xarxes al Neolític. Museu de Gavà, Gavà (Barcelona), pp. 307-314.

Blasco, A., Edo i Benaiges, M., Villalba, M.J., 1990. Les perles en callaïs du sud de la France proviennent-elles des mines de Can Tintorer? Archéologie en Languedoc Congrès Hommage au Dr Jean Arnal.Colloque international (20/09/1990), pp. 279-289

Blasco, A., Villalba, M.J., Edo i Benaiges, M., 1992. Cronologia del complex miner de Can Tintorer. Aportacions a la periodització del Neolític Mitjà Cátala. Estat de La Investigació Sobre El Neolític a Catalunya. 9è Col · loqui International d'Arqueologia de Puigcerdà. Ajuntament de Puigcerdà, Puigcerdà, pp. 215-219.

Blasco, A., Villalba, M.J., Edo i Benaiges, M., 1997. Aspectos sociales del Neolítico Medio catalán. In: Balbín Behrmann, R., Bueno Ramírez, P. (Eds.), II Congreso de Arqueología Peninsular. Neolítico, Calcolítico y Bronce. Fundación Rei Afonso Henriques, Zamora, pp. 89-98.

Boaventura, R., 2011. Chronology of Megalithism in South-Central Portugal. In: García Sanjuán, L., Scarre, C., Wheatley, D. (Eds.), Exploring Time and Matter in Prehistoric Monuments: Absolute Chronology and Rare Rocks in European Megaliths. Junta de Andalucía, Sevilla, pp. 159-192.

Borrell, F., Bosch, J., Vicente, O., 2009. Datacions per radiocarboni a les mines neolítiques de la serra de les Ferreres de Gavà. In: Bosch, J., Borrell, F. (Eds.), Intervencions arqueològiques a les Mines de Gavà (sector serra de les Ferreres). Anys 1998-2009. Museu de Gavà, Gavà (Barcelona), pp. 241-246.

Bosch, J., Estrada, A., 1994. El neolític postcardial a les mines prehistòriques de Gavà (Baix Llobregat). Museu de Gavà, Gavà (Barcelona).

Bosch, J., Estrada, A., 1995. La mineria en Gavá (Bajo Llobregat) durante el IV milenio AC Rubricatum 1, 265-270.

Bueno Ramírez, P., Barroso Bermejo, R., de Balbín Behrmann, R., 2005. Ritual campaniforme, ritual colectivo: la necrópolis de cuevas artificiales del Valle de las Higueras, Huecas, Toledo. Trabajos de Prehistoria 62, 67-90.

Burbidge, C.I., Sanderson, D.C.W., Housley, R.A., Allsworth Jones, P., 2007. Survey of Palaeolithic Sites by Luminescence Profiling, a Case Study from Eastern Europe. Quaternary Geochronology 2, 296-302.

Burbidge, C.I., 2012. Facets of luminescence for dating. Spectroscopy Letters 45, 118-126.

Burbidge, C.I., 2015. A broadly applicable function for describing luminescence dose response. Journal of Applied Physics 118, 044904. http://dx.doi.org/10.1063/1 4927214.

Burbidge, C.I., Duller, G.A.T., Roberts, H.M., 2006. De determination for young samples using the standardised OSL response of coarse grain quartz. Radiation Measurements 41, 278-288.

Burbidge, C.I., Sanderson, D.C.W., Fülop, R., 2008. Luminescence Dating of Ditch Fills From the Headland Archaeology Ltd. Excavation of Newry Ring Fort, Northern Ireland, Glasgow, SUERC. University of Glasgow (91 pp).

Burbidge, C.I., Trindade, M.J., Cardoso, G.J.O., Dias, M.I., Oosterbeek, L., Cruz, A., Scarre, C., Cura, P., Caron, L., Prudêncio, M.I., Gouveia, A., Franco, D., Marques, R., 2014. Luminescence dating and associated analyses in transition landscapes of the Alto Ribatejo, Central Portugal. Quaternary Geochronology 20, 65-77.

Burleigh, R., Matthews, K., Ambers, J., 1982. British Museum natural radiocarbon measurements XIV. Radiocarbon 24, 229-261.

Campano Lorenzo, A., Rodriguez Marcos, J.A., Sanz Mínguez, C., 1985. Apuntes para una primera valoración de la explotación y comercio de la variscita en la Meseta Norte. Anuario del Instituto de Estudios Zamoranos Florián de Ocampopp. 13-22.

Cardoso, J.L., 2010. O povoado calcolítico da Penha Verde (Sintra). Estudos Arqueológicos de Oeiras 18, 467-551.

Cardoso, J.L., 2014. Cronología absoluta del fenómeno campaniforme al Norte del estuario del Tajo: implicaciones demográficas y sociales. Trabajos de Prehistoria $71,56-75$.

Cardoso, J.L., Caninas, J.C., 2010. Moita da Ladra (Vila Franca de Xira). Resultados preliminares da escavação integral de um povoado calcolítico muralhado. In: Gonçalves, V.S., Sousa, A.C. (Eds.), Transformação E Mudança No Centro E Sul de Portugal: O 4.o E O 3.o Milénios A.n.e. (Cascais, 2005), pp. 65-95 (Cascais, Cascais).

Cardoso, J.L., Carreira, J.R., Ferreira, O. da V., 1996. Novos elementos para o estudo do Neolítico antigo da região de Lisboa. Estudos Arqueológicos de Oeiras 6, 9-26.

Castro Martínez, P.V., Lull, V., Mico, L.R., 1996. Cronología de la Prehistoria Reciente de la Península Ibérica y Baleares (c. 2800-900 cal ANE). Archaeopress, Oxford.

Collet, H., 2004. Les Mines Neolithiques de Spiennes - Etat Des Connaissances et Perspectives de Recherche., 2004. Actes Du XIVème Congrès de l'UISPP. Bar International series 1303. Archaeopress, Oxford.

Collet, H., Hauzeur, A., Lech, J., 2008. The prehistoric flint mining complex at Spiennes (Belgium) on the occasion of its discovery 140 years ago. In: Allard, P., Bostyn, F., Giligny, F., Lech, J. (Eds.), Flint Mining in Prehistoric Europe Interpreting the Archaeological RecordsBAR International Series 1891. Archaeopress, Oxford.

Costa, M.E., García Sanjuán, L., Murillo-Barroso, M., Parrilla Giráldez, R., Wheatley, D.W. 2011. Artefactos elaborados en rocas raras en los contextos funerarios del IV-Il milenios cal ANE en el sur de España: Una revisión. Menga 1, 253-294.

Craddock, P.T., 1995. Early Metal Mining and Production. Edinburgh University Press, Edinburgh.

de Blas Cortina, M.A., 1998. Producción e intercambio de metal: la singularidad de las minas de cobre prehistóricas de El Aramo y El Milagro (Asturias). In: Delibes, G. (Ed.), Minerales y metales en la Prehistoria Reciente. Algunos testimonios de su explotación y laboreo en la península ibérica. Universidad de Valladolid, Valladolid, pp. 71-103. 
de Blas Cortina, M.A., 2011. Las minas prehistóricas del norte de España en el contexto de la paleominería del cobre del Occidente de Europa. In: Mata-Perelló, J.M., Torró, L. Fuentes, N.M. (Eds.), Actas del V Congreso Internacional sobre minería y Metalurgia Históricas en el Suroeste Europeo. SEDPGYM, MADRID, pp. 101-130.

Deckers, K., Sanderson, D.C.W., Spencer, J.Q., 2005. Thermoluminescencescreening of nondiagnostic sherds from stream sediments to obtain apreliminary alluvial chronology: an example from Cyprus. Geoarchaeology 20, 67-77.

Delibes de Castro, G., Rojo Guerra, M.Á., 1997. C14 y Secuencia megalítica en la Lora Burgalesa: Acotaciones a la problemática de las dataciones absolutas referentes a yacimientos dolménicos. In: Rodríguez Casal, A.A. (Ed.), O neolitico atlántico e as orixes do megalitismo. Universidad de Santiago de Compostela, Santiago de Compostela, pp. 391-415.

Dias, M.I., Prudêncio, M.I., 2007. Neutron activation analysis of archaeological materials: an overview of the ITN NAA laboratory, Portugal. Archaeometry 49, 383-393.

Dias, M.I., Prudêncio, M.I., Matos, M.A., Rodrigues, A.L., 2013. Tracing the origin of blue and white Chinese Porcelain ordered for the Portuguese market during the Ming dynasty using INAA. Journal of Archaeological Science 40 (7), 3046-3057. http://dx.doi.org/ 10.1016/j.jas.2013.03.00.

Díaz del Rio, P., Consuegra Rodríguez, S., 2011. Time for action. The chronology of mining events at Casa Montero (Madrid, Spain). In: Capote, M., Consuegra, S., Díaz-del-Río, P. Terradas, X. (Eds.), Proceedings of the 2nd International Conference of the UISPP Commission on Flint Mining in Pre- and Protohistoric Times. Archaeopress, Oxford, pp. 221-229.

Díaz delRio, P., Consuegra Rodríguez, S., Capote, M., Castañeda, N., Criado, C., Vicent García, J.M., Orozco Köhler, T., Terradas Batlle, X., 2008. Estructura, contexto y cronología de la mina de sílex de Casa Montero (Madrid). IV Congreso del Neolítico Peninsular. Museo Arqueológico de Alicante-MARQ Alicante, pp. 200-207.

Domergue, C., 1990. Les mines de la péninsule Ibérique dans l'Antiquité Romaine, Collection de l'Ecole Francaise de Rome. École française de Rome, Roma.

Dominguez Bella, S., 1996. Caracterización mineralógica y petrológica de algunos objetos del ajuar y de los recubrimientos de las paredes y suelos de la cámara (materiales líticos y ocres). In: Ramos Muñoz, J., Giles Pacheco, F. (Eds.), El Dolmén de Alberite (Villamartin). Aportaciones a Las Formas Económicas Y Sociales de Las Comunidades Neolíticas En El Noroeste de Cádiz. Servicio de PUblicaciones de la Universidad de Cádiz, Cádiz, pp. 187-206.

Dominguez Bella, S., 2004. Variscite, a prestige mineral in the Neolithic-Aneolithic Europe. Raw material sources and possible distribution routes. Slovak Geological Magazine 10, 147-152.

Dominguez Bella, S., 2012. Archaeomineralogy of prehistoric artifacts and gemstones. In: Herrero, J.M. Vendrell-Saz, M. (Eds.), Sociedad Española de Mineralogía. Museo Geominero del Instituto Geológico y Minero de España, España, pp. 5-28.

Dominguez Bella, S., Bóveda, M.J., 2011. Variscita y ámbar en el Neolítico gallego. Análisis arqueométrico del collar del túmulo 1 de Chousa Nova, Silleda (Pontevedra, España). Trabajos de Prehistoria 68, 369-380. http://dx.doi.org/10.3989/tp.2011.11075.

Edo i Benaiges, M., Fernández Turiel, J.L., 1997. Las cuentas de collar de calaita del dolmen del Prado de las Cruces. Bernuy-Salinero (Ávila). In: Fabián García, J.F. (Ed.), E Dolmen Del Prado de Las Cruces. Bernuy-Salinero (Ávila). Junta de Castilla y León, Valladolid.

Edo i Benaiges, M., Blasco, A., Villalba, M.J., 1990. Approche de la carte de distribution de la variscite de can Tintorer, Gavà (Catalogne). Cahiers du Quaternaire 17, 287-298.

Edo i Benaiges, M., Villalba, M.J., Blasco, A., 1995a. La Calaíta en la Península Ibérica. In: Jorge, V.O. (Ed.), 1o Congresso de Arqueologia PeninsularTrabalhos de Antropología e Etnología. Sociedade portuguesa de Antropologia e Etnologia, Porto, pp. 127-168.

Edo i Benaiges, M., Blasco, A., Villalba, M.J., Gimeno, D., Fernández Turiel, J.L., Plana, F. 1995b. La caracterización de la variscita del complejo minero de Can Tintorer, una experiencia aplicada al conocimiento del sistema de bienes de prestigio durante e neolítico. In: Bernabeu, J., Orozco Köhler, T., Terradas, X. (Eds.), Los Recursos Abióticos En La Prehistoria. Caracterización, Aprovisionamiento E Intercambio. Universitat de Valencia, pp. 83-110.

Esparza Arroyo, A., Larrazabal Galarza, J., 2000. El castro de la Mazada (Zamora): elementos metálicos y contexto peninsular. In: Oliveira Jorge, V. (Ed.), 3o Congresso de Arqueología Peninsular: UTAD, Vila Real, Portugal, Setembro de 1999. ADECAP, Porto, pp. 433-476.

Fabián García, J.F., 2006. El IV y III milenio AC en el Valle Amblés (Ávila). Junta de Castilla y León, Valladolid.

Fernández Turiel, J.L., Gimeno, D., Cabañas, M., López Soler, A., 1996. Análisis de materiales arqueológicos mediante ablación por Laser-ICP-MS. In: I Congrés del Neolític a la Península Ibérica. Formació i implantació de les comunitats agrícoles vol. 1.Museu de Gavà, Barcelona, pp. 223-225.

Forestier, F.H., Lasnier, B., L'Helgouach, J., 1973a. À propos de la “callaïs”, découverte d'un gisement de variscite à Pannecé (Loire-Atlantique), analyse de quelques "perles vertes" néolithiques. Bulletin de la Société Préhistorique Française 70, 173-180.

Forestier, F.H., Lasnier, B., L'Helgouach, J., 1973b. Découverte de minyulite en échantillons spectaculaires, de wavellite et de variscite dans les phtanites siluriens près de Pannecé (Loire-Atlantique). Bulletinde la Société Minéralogique de Cristallographie $96,67-71$.

Frumkin, A., Bar-Matthews, M., Davidovich, U., Langford, B., Porat, R., Ullman, M., Zissu, B. 2014. In-situ dating of ancient quarries and the source of flowstone ("calcitealabaster") artifacts in the southern Levant. Journal of Archaeological Science 41, 749-758. http://dx.doi.org/10.1016/j.jas.2013.09.025

García-Guinea, J., Sapalski, C., Cardenes, V., MLombardero, M., 2000. Mineral inlays in natural stone slabs: techniques, materials and preservation. Construction and Building Materials 14, 365-373.

Gonçalves, V.S., 2002. Quelques questions autor du temps, de l'espace et des symboles mégalithiques du Centre et du Sud Poryugal. Origine et Développement D Mégalithisme de L'ouest de l'Europe (Bougon - 26/30 Octobre 2002), pp. 485-830.
Goncalves, V.S. 2003. A Anta 2 da Herdade dos Cebolinhos (Reguengos de Monsaraz, Évora): sinopse das intervenções de 1996-97 e duas datações de radiocarbono para a última utilização da Câmara ortostática. Revista Portuguesa de Arqueología 8, 143-188.

Gonçalves, V.S., 2005. Cascais há 5000 mil anos. Tempos, símbolos e espaços da Morte das antigas Sociedades Camponesas. Cámara Municipal de Cascais, Cascais.

Gonçalves, Victor S., 2008. As Ocupações Pré-Históricas Das Furnas Do Poço Velho (Cascais). Cámara Municipal de Cascais, Cascais.

Gonçalves, A.A.H. de B., Reis, M. de L., 1982. Estudo mineralógico de elementos de adorno de cor verde provenientes de estações arqueológicas portuguesas. Portugalia Nova série 2-3, 153-166.

Gouveia, M.A., Prudêncio, M.I., 2000. New data on sixteen reference materials obtained by INAA. Journal of Radioanalytical and Nuclear Chemistry 245, 105-108.

Guitán Rivera, F., Vázquez-Varela, J.M., 1975. Análisis radiográfico de cuentas de calaíta gallegas. Boletín de la Comisión de Monumentos de Lugo 9, 187-188.

Gutiérrez Pérez, J., Villalobos García, R., Odriozola, C.P., 2015. El uso de la variscita en Hispania durante a Época Romana. Análisis de composición de objetos de adorno y teselas de la zona noroccidental de la Meseta Norte. SPAL 24, 165-181.

Herbaut, F., Querré, G., 2004. La parure néolithique en variscite dans le sud de l'Armorique. Bulletin de la Société préhistorique française 101, 497-520. http://dx. doi.org/10.3406/bspf.2004.13029.

Hunt, M., 1996. Prospección arqueológica de carácter minero y metalúrgico: fuentes y restos. Acontia 2, 19-28.

Hunt, M., 2003. Prehistoric Mining and Metallurgy in South-West Iberian Peninsula. Archaeopres, Oxford.

Jiménez Gómez, M.C., 1995. Zambujal. Los amuletos de las campañas 1964 hasta 1973. In: Sangmeister, E., Jiménez Gómez, M.C. (Eds.), Zambujal: Kupferfunde Aus Den Grabungen 1964 Bis 1973 - Los Amuletos de Las Campañas 1964 Hasta 1973. Philipp von Zabern, Mainz am Rhein, pp. 155-238.

Jubes, E., Carbonell, A., 1920. Estudio geológico-industrial de los yacimientos minerales del término municipal de Encinasola y la Contienda de Moura (Portugal). Boletín Oficial de Minas y Metalúrgia 34-38.

Kunst, M., Lutz, N., 2011. Zambujal (Torres Vedras), Investigações até 2007. Parte 1: Sobre a precisão da cronologia absoluta decorrente das investigações na quarta linha da fortificação. Estudos Arqueologicos de Oeiras 18, 419-466.

Larsen, E.S., 1942. The mineralogy and paragenesis of the variscite nodules from Near Fairfield, Utah part 1. American Mineralogist 27, 281-300.

Lheur, C., 1993. Les minéralisations de l'ancienne carrière de La Floquerie près de Pannecé (Loire-Atlantique). Le Cahier des Micromonteurs 4, 14-21.

Linares Catela, J.A., García Sanjuán, L., 2010. Contribuciones a la cronología absoluta del megalitismo andaluz. Nuevas fechas radiocarbónicas de sitios megalíticos del Andévalo oriental (Huelva). Menga 1, 134-151.

Marini, C., Gimeno, D., Sistu, G., 1989. Le mineralizzazioni a variscite del Sarrabus. Bollettino della Societa Geologica Italiana 108, 357-367.

Massé, R., 1971. Découvert de minyulite, wavellite et variscite dans les phtanites de Pannecé. Bulletin de la Société Sciences naturelles Ouest de la France LXIX, 12-15.

Meireles, C. Ferreira, N., Lourdes Reis, M., 1987. Variscite occurrences in Silurian Formations from Northern Portugal. Comunicações dos Serviços Geológicos de Portugal 73, 21-27.

Moro, M.C., Cembranos Pérez, M.L., Fernández Fernández, A., 1995. Estudio mineralógico de las variscitas y turquesas silúricas de Punta Corveiro (Pontevedra, Españ). Geogaceta 18, 176-179.

Murillo-Barroso, M., Martinón-Torres, M., 2012. Amber sources and trade in the prehistory of the Iberian Peninsula. European Journal of Archaeology 15, 187-216.

Murillo-Barroso, M., Montero Ruiz, I., 2012. Copper ornaments in the Iberian Chalcolithic: technology versus social demand. Journal of Mediterranean Archaeology 25, 53-73.

Murray, A.S., Wintle, A.G., 2000. Luminescence dating of quartz using an improved singlealiquot regenerative-dose protocol. Radiation Measurements 32, 57-73.

Nocete, F., Linares, J.A., 1999. Las primeras sociedades mineras en Huelva. Alosno. Historia de La Provincia de Huelva. Madrid, pp. 49-64.

Odriozola, C.P., 2014. A new approach to determine the geological provenance of variscite artifacts using the $\mathrm{P} / \mathrm{Al}$ atomic ratios. Archaeological and Anthropological Sciences 6 , 1-22. http://dx.doi.org/10.1007/s12520-014-0195-2.

Odriozola, C.P., Villalobos García, R., 2015. La explotación de variscita en el Sinforme de Terena: el complejo minero de Pico Centeno (Encinasola, Huelva). Trabajos de Prehistoria $72(2)$

Odriozola, C.P., Hurtado, V., Dias, M.I., Prudêncio, M.I., 2008. Datación por técnicas luminiscentes de la tumba 3 y el conjunto campaniforme de La Pijotilla (Badajoz, España)./Luminiscence Dating of Burial 3 and the Bell Beaker pottery from La Pijotilla (Badajoz, Spain). VIII Congreso Ibérico de Arqueometría. ACTAS. Instituto de Historia (CSIC), Museo Arqueológico Nacional y SAPaC, pp. 211-225.

Odriozola, C.P., Linares Catela, J.A., Hurtado, V., 2010. Variscite source and source analysis: testing assumptions at Pico Centeno (Encinasola, Spain). Journal of Archaeological Science 37, 3146-3157.

Odriozola, C.P., Burbidge, C.I., Dias, M.I., Hurtado, V., 2014. Dating of Las Mesas Copper Age walled enclosure (La Fuente, Spain). Trabajos de Prehistoria 71, 343-352.

Oliveira, J., 2000. O megalitismo de xisto da Bacia do Sever (Montalvão-Cedillo). In: Gonçalves, V.S. (Ed.), Muitas Antas, Pouca Gente?Instituto Português de Arqueología, Lisboa.

Oliveira, J., 2010. Neolítico e megalitismo na Coudelaria de Alter. Transformação E Mudanza No Centro E Sul de Portugal: O 4.o E O 3.o Milénios A.n.e. Cámara Municipal de Cascais, Cascais.

Pavón Soldevila, I. 1994. El mundo funerario de la edad del bronce en la Tierra de Barros: una aproximación desde la bio-arqueología de Las Minitas. Mem. Campaña Urgenc. De 2008-141.

Pérez Macías, J.A., 2008. Recursos minerales de cobre y minería prehistórica en el suroeste de España. Verdolay 11, 9-36. 
Pérez Macías, J.A., 2011. Las minas de Encinasola (Huelva). La explotación de un campo filoniano de Ossa Morena. De Re Metallica 16, 1-10.

Pétrequin, P., Errera, M., Petrequin, A.-M., Allard, P., 2006. The Neolithic Quarries of Mont Viso, Piedmont, Italy: initial radiocarbon dates. European Journal of Archaeology 9, 7-30.

Prescott, J.R., Hutton, J.T., 1988. Cosmic-ray and gamma-ray dosimetry for TL and electron-spin-resonance. Nuclear Tracks and Radiation Measurements 14, 223-227.

Prescott, J.R., Stephan, L.G., 1982. The contribution of cosmic radiation to the environmental dose for thermoluminescent dating. Latitude, altitude and depth dependencies. Council of Europe PACT Journal 6, 17-25.

Prudêncio, M.I., Oliveira, F., Dias, M.I., Sequeira Braga, M.A., Delgado, M., Martins, M., 2006. Raw materials sources used for the manufacture of Roman "Bracarense" ceramics from NW Iberian Peninsula. Clays and Clay Minerals 54 (5), 639-651.

Querré, G., Herbault, F., Calligaro, T., 2008. Transport of Neolithic variscites demonstrated by PIXE analysis. X-Ray Spectrometry 37, 116-120.

Querré, G., Calligaro, T., Domínguez-Bella, S., Cassen, S., 2014. PIXE analyses over a long period: the case of Neolithic variscite jewels from Western Europe (5th-3th millennium BC). Nuclear Instruments and Methods in Physics Research Section B: Beam Interactions with Materials and Atoms 318, 149-156.

Real, Fernando, 1992. Estudo Mineralógico de Adornos de Cor Verde Do Neolítico Antigo Da Gruta Do Caldeirão. In: Zilhão, João (Ed.), Gruta Do Caldeirão O Neolítico Antigo. Lisboa: Trabalhos de Arqueología 6, Instituto Português do Patrimonio Arquitectónico e Arqueológico. Departamento de Arqueología, pp. 315-319.

Reimer, P.J., Edouard Bard, A.B., Beck, J.W., Blackwell, P.G., Ramsey, C.B., Buck, C.B., et al., 2013. IntCal13 and Marine13 radiocarbon age calibration curves $0-50,000$ years cal BP. Radiocarbon 55, 1869-1887. http://dx.doi.org/10.2458/azu_js_rc.55.16947.

Roberts, H.M., Duller, G.A.T., 2004. Standardised growth curves for optical dating of sediment using multiple grain aliquots. Radiation Measurements 38, 241-252.

Rodrigues, A.L., Burbidge, C.I., Dias, M.I., Rocha, F., Valera, A., Prudêncio, M.I., 2013. Luminescence and mineralogy of profiling samples from negative archaeological features. Mediterranean Archaeology and Archaeometry 13 (3), 37-47.

Rojo Guerra, M.Á., Delibes de Castro, G., Edo i Benaiges, M., Fernández Turiel, J.L., 1996. Adornos de calaíta en los ajuares dolménicos de la provincia de Burgos: Apuntes sobre su composición y procedencia. I Congrés del Neolític a la Península Ibérica. Rubricatum 1, 239-250.

Rothenberg, B., Frejeiro, A.B., 1980. Ancient copper mining and smelting at Chinflón (Huelva SW Spain). British Museum Occasional Papers 20, 41-62.

Sanderson, D.C.W., Murphy, S., 2009. Using simple portable OSL measurements and laboratory characterisation to help understand complex and heterogeneous sediment sequences for luminescence dating. Quaternary Geochronology 20, 893-900.

Sanderson, D.C.W., Bishop, P., Houston, I., Boonsener, M., 2001. Luminescence characterisation of quartz-rich cover sands from NE Thailand. Quaternary Science Reviews 20, 893-900.

Santos Arevalo, F.J., Gómez Martínez, I., Garcia Leon, M., 2009. Radiocarbon measurement programme at the Centro Nacional de Aceleradores (CNA). Radiocarbon 883-889.

Sanz Mínguez, C., Campano Lorenzo, A., Rodríguez Marcos, J.A., 1990. Nuevos datos sobre la dispersión de la variscita en la Meseta Norte: las explotaciones de época romana. Primer Congreso de Historia de ZamoraTomo 2. Prehistoria E Historia Antigua. Instituto de Estudios Zamoranos Florián de Ocampo, Zamora, pp. 747-764.

Schiffer, M.B., 1986. Radiocarbon dating and the "old wood" problem: the case of the Hohokam chronology. Journal of Archaeological Science 13, 13-30. http://dx.doi. org/10.1016/0305-4403(86)90024-5.

Schubart, H., Pingel, V., Kunter, M., Liesau von Lettow-Virbeck, C., Pozo, M., Medina, J.A., Casas, J., Tresserras, J.J., Hägg, I., 2004. Studien zu Grab 111 von Fuente Álamo (Almería). Madrider Mitteilungen 45, 57-146.

Schuhmacher, T.X., 2012. El marfil en España desde el Calcolítico al Bronce Antiguo. In: Banerjee, A., López Padilla, J.A., Schuhmacher, T.X. (Eds.), Elfenbeinstudien faszikel 1. Marfiles y elefantes en la península Ibérica y el Mediterráneo Occidental, Iberia Archaeologica. Mainz, Verlag Philipp von Zabern, pp. 45-68.

Schuhmacher, T.X., Cardoso, J.L., Banerjee, A., 2009. Soucing African ivory in Chalcolithic Portugal. Antiquity 83, 983-997.

Senna-Martínez, J.C., Quintã Ventura, J.M., 2000. Os primeiros constructores de megalitos. En: Por Terras de Viriato. Arqueologia Da Região de Viseu. Museo Nacinal de Arqueologia, Viseu.

Shepherd, R., 1980. Prehistoric Mining and Allied Industries, Studies in Archaeological Science. Academic Press, London.
Silva, A.M., 2003. Evidence of osteochronditis dissecans in late neolithic/chalcolithic Portuguese populations. Dónde Estamospp. 464-468.

Silva, A.M., Wasterlain, S.N., 2010. A possible case of an ossifying fibroma in a Late Neolithic population from Portugal. International Journal of Osteoarchaeology 20, 579-585.

Soares, J., 2010. Dólmen da Pedra Branca. Datas radiométricas. Musa. Museus, Arqueologia e Outros Patrimónios 3, 71-82.

Soares, J., Sllva, C., 2010. Anta Grande do Zambujeiro - arquitectura e poder. Intervenção arqueológica do MAEDS, 1985-87. Musa. Museus, Arqueologia e Outros Patrimónios $3,83-129$

Sousa, A.C., 2010. Penedos e muralhas. A leitura possível das fortificaçoes do Penedo do Lexim. In: Gonçalves, V.S., Sousa, A.C. (Eds.), Transformação E Mudanza No Centro E Sul de POrtugal: O 4.o E O 3.o Milénios A.n.e. Cámara Municipal de Cascais, Cascais.

Sttip, J.J., Tamers, M.A., 1996. Dataciones absolutas. In: Ramos Muñoz, J., Giles Pacheco, F. (Eds.), El Dolmen de Alberite (Villamartín). Aportaciones a Las Formas Económicas Y Sociales de Las Comunidades Neolíticas En El Noroeste de Cádiz. Servicio de publicaciones de la Universidad de Cádiz, Salamanca, pp. 179-186.

Stuiver, M., Polach, H.A., 1977. Discussion: reporting 14C data. Radiocarbon 19, 255-363.

Stuiver, M., Reimer, P.J., 1993. Extended 14C data base and revised CALIB $3.014 \mathrm{C}$ age calibration program radiocarbon. Radiocarbon 35, 215-230.

Tarriño, A., Lobo, P.J., García-Rojas, M., Elorrieta, I., Orue, I., Bento-Calvo, A., Karampanglidis, T., 2011. Introducción al estudio de las minas neolíticas de sílex de la Sierra de Araico (Condado de Treviño): campaña de excavación del 2011. Estudios de Arqueología Alavesa. 27, 4-81.

Trindade, M.J., Prudêncio, M.I., Burbidge, C.I., Dias, M.I., Cardoso, G., Marques, R., Rocha, F., 2013. Distribution of naturally occurring radionuclides (K, Th and $U$ ) in weathered rocks of various lithological types from the uranium bearing region of Fornos de Algodres, Portugal. Mediterranean Archaeology and Archaeometry (ISSN: 1108-9628) 13 (3), 71-79.

Trindade, M.J., Prudêncio, M.I., Burbidge, C.I., Dias, M.I., Cardoso, G., Marques, R., Rocha, F., 2014. Study of an aplite dyke from the Beira uraniferous province in Fornos de Algodres area (Central Portugal): trace elements distribution and evaluation of natural radioactivity. Applied Geochemistry 44, 111-120.

Valera, A.C., Silva, A.M., Márquez Romero, J.E., 2014. La temporalidad del recinto de fosos de Perdigões: cronología absoluta de estructuras y prácticas sociales. Spal 23, 11-26. http://dx.doi.org/10.12795/spal.2014i23.01.

Villalba, M.J., 2002. Le gîte de variscite de Can Tintorer: production, transformation et circulation du minéral vert. In: Guilaine, J. (Ed.), Matériaux, Productions, Circulations Du Neolithique À l'Age Du Bronze. Séminaire Du Collège Du France, Errance, Paris, pp. 115-130.

Villalba, M.J., Edo i Benaiges, M., Blasco, A., 2001. La callaïs en Europe du Sud-Ouest. État de la question. In: Le Roux, C.-T. (Ed.), Du monde des chasseurs à celui des métallurgistes, Revue Archéologique de l'Ouest. Suppléments. Université Rennes I, pp. 267-276.

Villalobos García, R., 2012. Adornos exóticos en los sepulcros tardoneolíticos de la Submeseta Norte Española. El ejemplo de Las Tuerces como nodo de una red descentralizada de intercambiosActes Xarxes al Neolític. Museu de Gavà, Gavà (Barcelona), pp. 265-271.

Villalobos García, R., 2014. The megalithic tombs of the Spanish Northern Meseta. Material, political and ideological tie between the Neolithic people and their territory. Colloque Internationel Fonctions, Utilisations et Représentations de L'espace Dans Les Sépultures Monumentales Du Néolithique EuropéenPréhistoires Méditerranéennes, s4. Maison Méditerranéenne Des Sciences de L'homme. CNRS, Université de Provence, Aix-en-Provence.

Virgilio Sevillano, F., 1978. Testimonio arqueológico de la provincia de Zamora. Instituto de Estudios Zamoranos "Florian do Campo", Zamora.

Waterman, A.J., 2012. Marked in Life and Death: identifying Biological Markers of Social Differentiation in Late Prehistoric Portugal.

Weisgerber, G., Willies, L., 2000. The use of fire in prehistoric and ancient mining: firesetting. Paléorient 131-149.

Whittle, A.W.R., Healy, F.M.A., Bayliss, A., 2011. Gathering Time: Dating the Early Neolithic Enclosures of Southern Britain and Ireland. Oxbow Books.

Willies, L., 1994. Firesetting technology. Bulletin of the Peak District Mines Historical Society 12. 